\title{
IfIISGUC.ORG
}

"İȘ, GÜC̣" ENDÜSTRi ilLișKiLERI VE INSAN KAYNAKLARI DERGISi

"IS, GUC" INDUSTRIAL RELATIONS AND HUMAN RESOURCES JOURNAL

\section{İssizlik Ve Yoksulluk Sorununu Çözmeye Yönelik İstihdam/Gelir Garantisi Politikalarının Uygulanabilirliği: Antalya Örneği}

\author{
Feasibility Of Employment And Income Guarantee \\ Policies In Solving Unemployment And Poverty \\ Problems: The Case Of Antalya
}

\section{Sayım IŞIK}

Doç. Dr./Akdeniz Üniversitesi, İktisadi ve İdari Bilimler Fakültesi

\section{Mehmet MERT}

Yrd. Doç. Dr./ Akdeniz Üniversitesi, İktisadi ve İdari Bilimler Fakültesi

Ocak/January 2011, Cilt/Vol: 13, Say1/Num: 1, Page: 51-80 ISSN: 1303-2860, DOI: 10.4026/1303-2860.2010.0165.x

Makalenin on-line kopyasına erişmek için:

http://www.isguc.org/?p=article\&id=448\&vol=13\&num=1\&year=2011

To reach the on-line copy of article:

http://www.isguc.org/?p=article\&id=448\&vol=13\&num=1\&year=2011

Makale İçin İletişim/Correspondence to: 
(C) 2000- 2011

"İşGüç" Endüstri İlişkileri ve İnsan Kaynakları Dergisi

"İşGüç" Industrial Relations and Human Resources Journal

Ocak/January 2011, Cilt/Vol: 13, Say1/Num: 1

ISSN: 1303-2860, DOI: 10.4026/1303-2860.2010.165.x

Editör/Editor-in-Chief

Aşkın Keser (Kocaeli University)

Editör Yardımcıları/Co-Editors

K.Ahmet Sevimli (Uludağ University)

Gözde Yılmaz (Kocaeli University)

Uygulama/Design

Yusuf Budak (Kocaeli Universtiy)

\author{
Yayın Kurulu / Publishing Committee \\ Dr.Zerrin Firat (Uludăg University) \\ Doç.Dr.Aşkın Keser (Kocaeli University) \\ Prof.Dr.Ahmet Selamoğlu (Kocaeli University) \\ Yrd.Doç.Dr.Ahmet Sevimli (Uludağ University) \\ Yrd.Doç.Dr.Abdulkadir Şenkal (Kocaeli University) \\ Yrd.Doç.Dr.Gözde Yilmaz (Kocaeli University) \\ Dr.Memet Zencirkıran (Uludağ University)
}

Uluslararası Danışma Kurulu / International Advisory Board

Prof.Dr.Ronald Burke (York University-Kanada)

Assoc.Prof.Dr.Glenn Dawes (James Cook University-Avustralya)

Prof.Dr.Jan Dul (Erasmus University-Hollanda)

Prof.Dr.Alev Efendioğlu (University of San Francisco-ABD)

Prof.Dr.Adrian Furnham (University College London-İngiltere)

Prof.Dr.Alan Geare (University of Otago- Yeni Zellanda)

Prof.Dr. Ricky Griffin (TAMU-Texas AEM University-ABD)

Assoc. Prof. Dr. Diana Lipinskiene (Kaunos University-Litvanya)

Prof.Dr.George Manning (Northern Kentucky University-ABD)

Prof. Dr. William (L.) Murray (University of San Francisco-ABD)

Prof.Dr.Mustafa Özbilgin (University of East Anglia-UK)

Assoc. Prof. Owen Stanley (James Cook University-Avustralya)

Prof.Dr.Işık Urla Zeytinoğlu (McMaster University-Kanada)

Danışma Kurulu / National Advisory Board

Prof.Dr.Yusuf Alper (Uludağ University)

Prof.Dr.Veysel Bozkurt (Uludağ University)

Prof.Dr.Toker Dereli (Işık University)

Prof.Dr.Nihat Erdoğmuş (Kocaeli University)

Prof.Dr.Ahmet Makal (Ankara University)

Prof.Dr.Ahmet Selamoğlu (Kocaeli University)

Prof.Dr.Nadir Suğur (Anadolu University)

Prof.Dr.Nursel Telman (Maltepe University)

Prof.Dr.Cavide Uyargil (İstanbul University)

Prof.Dr.Engin Yildırım (Sakarya University)

Doç.Dr.Arzu Wasti (Sabancı University)

Dergide yayınlanan yazllardaki görüşler ve bu konudaki sorumluluk yazarlarına aittir.

Yayınlanan eserlerde yer alan tüm içerik kaynak gösterilmeden kullanılamaz.

All the opinions written in articles are under responsibilities of the outhors.

None of the contents published can't be used without being cited. 


\title{
İşsizlik Ve Yoksulluk Sorununu Çözmeye Yönelik İstihdam/Gelir Garantisi Politikalarının Uygulanabilirliği: Antalya Örneği
}

\author{
Feasibility Of Employment And Income Guarantee Policies In \\ Solving Unemployment And Poverty Problems: The Case Of Antalya
}

\author{
Sayım IŞIK \\ Doç. Dr./
}

\author{
Mehmet MERT \\ Yrd. Doç. Dr./
}

\begin{abstract}
Özet:
Bu çalışma, işsizlik ve yoksullukla mücadelede istihdam/gelir garantisi politikalarını, bazı ülke deneyimlerini ve Antalya örneğini tartışmaktadır. Bu deneyimlerden hareketle bu politikaların Antalya ölçeğinde uygulanabilirliğini göstermeyi amaçlamaktadır. İşizlik ve yoksulluk problemleri, kapitalist ekonomilerin temel yapısal özellikleridir. Piyasalar, çalışmak isteyen fakat iş bulamayanlar için yeteri kadar istihdam yaratamadiğında hükümetlere sosyal adalet ve eşitliği sağlamak için önemli rol düşmektedir. İstihdam ve gelir garantisi politikaların savunanlara göre bu politikalar, kapitalist ekonomilerde tam istihdamın sağlanmasına yardım edebilir. Uluslararası deneyimler ise bu politikalarm finansal açıdan uygulanabileceğini göstermektedir. Bu kapsamda Antalya ölçeğinde istihdam ve gelir garantisi politikalarının finansal olarak uygulanabilirliği tartışılmaktadır. Antalya örneği, finansal uygulanabilirlik açısından uluslararası deneyimleri desteklemektedir.
\end{abstract}

Anahtar Kelimeler: İstihdam garantisi, gelir garantisi, işsizlik, yoksulluk, Antalya.

\begin{abstract}
:
This paper discusses employment/income guarantee policies for alleviating unemployment and poverty, some international experiences of goverment job creation programs and case of Antalya. Unemployment and poverty problems are permanent structural features of capitalist economies. When markets are unable to generate sufficient numbers of jobs for people who want to work but cannot find employment, goverments should play a role in providing jobs or basic income to achieve social justice and equity. Employment and income guarantee supporters suggest that goverment these policies might assist capitalist economies in attaining and maintaining full employment. International experiences show that for a sovereign nation, there is no question of the financial affordability of these policies. In context of these experiences the paper examines financial feasibility of employment guarantee and income guarantee policies for Antalya. The case of Antalya supports these international experiences in regard to financial feasibility.
\end{abstract}

Keywords: Employment guarantee, income guarantee, unemployment, poverty, Antalya

\footnotetext{
* Bu çalışma, 22-23 Ekim 2009 tarihleri arasında Akdeniz Üniversitesi tarafindan düzenlenen Uluslararası Sosyal Haklar Sempozyumu'nda sunulan "İşsizlik ve Yoksulluk Sorununu Çözmeye Yönelik İstihdam/Gelir Garantisi Politikasının Uygulanabilirliği: Antalya Örneği" başlıklı bildirinin gözden geçirilmiş ve genişletilmiş biçimidir.
} 


\section{GíRiş}

Son dönemlerde uygulanan neoliberal (ana-akım) iktisat politikaları nedeniyle büyüme, istihdam, yoksulluk, işsizlik, gelir dağılımı gibi temel ekonomik ve sosyal konularda öngörülen sonuçlar, tahmin edilenin çok altında gerçekleşmiştir. Son küresel kriz, bu geleneksel iktisat politikaların başarısızlığını ve piyasa ekonomisinin istihdamı çözmede yetersiz kaldığını açıkça teyit etmiştir (Mütevellioğlu ve Işık, 2009). Özellikle 1990'lardan günümüze gelişmiş ve gelişmekte olan ülkelerin emek piyasalarındaki rekabetçi ve esnek yapıya rağmen, doğal işsizlik oranı azalmak bir yana artış göstermiştir (Işık, 2009b). Ana akım iktisat politikalar, büyük ölçüde, sosyal politikaları dikkate almayan bir yaklaşımla uygulanmıştır. $\mathrm{Bu}$ politikaların yarattığ 1 yüksek işsizlikle birlikte artan yoksullaşma, gelir dağılımındaki uçurumlar, politik ve ekonomik gücün dağılımındaki adaletsizlikler, demokrasinin ve sosyal bar1şın sürdürülebilirliğini tehdit etmektedir.

Neoliberal yaklaşım, iktisat politikası (iyi) ile sosyal politika (kötü) arasında ayrım yapmış, iktisat politikasının minimal devlet ile birlikte yatırım ve büyüme için uygun bir ekonomik çevre yarattığını; sosyal politikanın ise sosyal güvence sağlayarak daha insani ve daha eşitlikçi bir toplum yaratarak yoksulları destekleyecek şekilde tasarlanmış olduğunu ileri sürmektedir. İktisat politikalarını ön plana ve sosyal politikayı geri plana iten bu yaklaşım ile 1980'lerden günümüze devletin sosyal hakları sağlama ve istihdam garantisi fonksiyonunu büyük ölçüde lağvedildi. Kamu işletmeleri özelleştirildi, kamu hizmetleri hızla azaltıldı ve geniş anlamda ekonominin tüm sektörleri serbestleştirildi (Antonopoulos, 2009). Devlet kamu mal ve hizmetleri sağlama fonksiyonundan çekilirken, iktisadi politikalar daha adil ve daha eşitlikçi bir toplum meydana getirmede başarısız olmuş ve toplumdaki eşitsizlikler iyice artmaya başlamıştır. Sosyal koruma politikalarının çoğu, telafi edici önlemlere dönüştü ve sosyal hak kavramından uzaklaştı. Gelir dağılımın bozukluğu, sefalet, is- tihdam olanaklarının azlığı, artan yoksulluk, yaşama standartlarının çok altında düşük ücretler, bölgesel göçler gibi sorunlar, yoksulluğu azaltıcı programlara havale edilen sosyal hastalıklar olarak tanımlandı.

1980'lerden bugüne ana akım iktisat felsefesinin geri plana attığ 1 sosyal politikalar, hayırseverlik anlayıșı içinde uygulanmaya başlandı. Devletin küçülmesini ve böylece devletin sosyal politikaları uygulama alanının daraltılmasını savunan bu yaklaşım, sosyal politikaları yardımsever-hayırsever kesimlere (sivil toplum kurumlarina) havale etmektedir. Devleti bu işin dişında tutan bu yaklaşım, sosyal hakları güçlendirmek yerine daraltmakta ve sosyal politikaların uygulanmasında hak yerine hayırseverlik anlayışını benimsemektedir. Bu dönemle birlikte devletin sosyal hak temelli anlayıştan uzak keyfi olarak dağıttığ sivil toplum kuruluşlarının hayırseverlik anlayışı içinde yaptığı yardımlar önem kazanmaya başladı. Bu anlayış devlet-birey arasındaki sosyal/siyasal sözleşmenin getirdiği vatandaş olmaktan kaynaklanan sosyal haklar anlayışı ile çelişmektedir.

Neoliberal politikaların son zamanlarda istihdam yaratmadaki başarısızlıkları ve bunun yarattığ 1 ekonomik, sosyal ve kültürel tahribatlar, toplumda başta çalışma hakk1 olmak üzere adil yaşama standardını garanti eden politikaların uygulanmasını gündeme getirdi. Geleneksel istihdam politikalarının yetersizlikleri, istihdam politikalarının daha geniş bir çerçevede ele alınmasına neden olmuştur (Wray, 2007 ve Mitchell ve Muysken, 2008). Sosyal politikaları yeniden kamu politikalarının bir parçası olarak ele alan devletin istihdam garantisi, gelir garantisi gibi yaklaşımlar gündeme geldi ve birçok ülkede uygulanmaya başlandı. Arjantin, Hindistan, Güney Afrika gibi ülkeler istihdamı garanti eden daha radikal önlemler almaya başlarken; Fransa, Avustralya gibi bazı gelişmiş ve Brezilya gibi bazı gelişmekte olan ülkeler de temel gelir politikasını uygulamaya koydu.

Türkiye'de son yıllarda hızla artan işsizlik ve yoksulluğa rağmen sınırlı ölçüde kullandırılan işsizlik sigortası ve keyfi-yetersiz 
sosyal yardımlar dışında geliştirilmiş herhangi bir politika bulunmamaktadır. Bu bağlamda son zamanlarda birçok ülkenin uygulamaya koyduğu istihdam garantisi ya da gelir garantisi politikalarının mali olarak uygulanabilirliğini Türkiye için tartışmak büyük önem arz etmektedir. Türkiye genelinde bu tür politikaların uygulanabilirliğiyle ilgili sınırlı sayıda çalışma bulunmakla birlikte Buğra ve Sinmazdenir (2007)'in yaptığı çalışma, nakit gelir desteği politikasının mali açıdan uygulanabilir olduğunu ileri sürmektedir. Diğer yandan, Türkiye'de yoksulluk çalışmaları büyük ölçüde TÜİK'in yaptığ1 hane halkı gelir ve tüketim harcamaları anketine dayanmaktadır. Mikro yani il düzeyinde yapılan yoksulluk çalışmaları ise oldukça sınırlıdır. Bunlardan birisi de Şengül ve Fisunoğlu (2009)'nun Adana ili için yaptığ1 yoksulluk çalışmasıdır. Ayrıca, yoksullukla mücadele politikalarının mali olarak uygulanabilirliği üzerindeki çalışmalar oldukça yetersizdir. Dolayısıyla il düzeyinde hem yapılan yoksulluk çalışmaları hem de yoksulluk politikaların olası maliyetleriyle ilgili oldukça az çalışma bulunmaktadır. Bu bağlamda bu çalışmanın diğerlerinden farklılığ1, il (Antalya) düzeyinde yoksulluk ve işsizlikle ilgili olarak istihdam/gelir garantisi politikalarının uygulanabilirliğini ampirik olarak incelemesidir. Çalışmanın diğgerlerinden bir diğer farkı ise, bu politikaların teorik temelleri ile birlikte uluslararası düzeydeki deneyimleri ele almasıdır.

Yukarıdaki özetlenen temel motivasyondan hareketle bu çalışmanın ikinci bölümünde istihdam ve gelir garantisi politikalarının teorik temelleri kısaca özetlenmektedir. Üçüncü bölümde uluslararası ülke deneyimlerinden hareketle bu politikaların uygulanabilirliği incelenmektedir. Dördüncü bölümde ise uluslararası deneyimlerden hareketle bu politika/politikaların Antalya ölçeğinde uygulanabilirliği ele alınacaktır.

\section{ISTIHDAM/GELIR GARANTISI POLITI- KALARI}

İşsizliğe ve yoksulluğa yönelik politika tercihleri incelendiğinde üç temel yaklaşım bulunmaktadır. Bunlardan ilki çalışma sürelerinin azaltılması, istihdam yardımları ve doğrudan devletin iş yaratması (istihdam garanti politikası) (Papadimitriou, 2008 ve 2009a ve Levy Institute, 2009). Çalışma sürelerinin azaltılmasına yönelik politikalar geçmişte Almanya (1950'li ve 1960'lı y1llar), Hollanda (1970'li ve 1980'li yıllar), Belçika (1980'li yıllar), Fransa (1990'li y1llar), Avusturalya (1980'li y1llar), Japonya (1990'l1 y1llar) gibi ülkelerde uygulanmış fakat istihdamı arttıramadığ 1 için başarısız olmuştur (Papadimitriou, 2009a ve Wray, 2007). Bugünkü küresel kriz koşullarında Amerika Birleşik Devletleri'nde birçok eyalet, Almanya, Fransa, Hollanda, Finlandiya, Yunanistan gibi birçok ülke, kısa çalışma programı adı altında bu politikaları yürütmeye çalışmaktadır.

İstihdam yardımı politikası ise, benzer şekilde geçmişte uygulanmış en eski politikalardan birisidir. $\mathrm{Bu}$ politikaya göre firmaların istihdam ettikleri her ilave işçi için maliyetlerin bir kısmını hükümet karşılamaktadır. Fakat bu istihdam politikaları istihdamı daha fazla arttırmada başarısız olmuş ve devletin katkı sağladığ 1 işsizler mevcut işçilerin yerini almıştır. İstihdam yardım politikaları içinde ücret yardımlarını kapsayan bir dizi önlemler de uygulanmıştır (Papadimitriou, 2008 ve 2009). Fakat bu uygulamalar iyi niyetli olmasına karşın, başarısız olmuştur. Bu politikalar, işverenin kararlarına müdahale ederek piyasa mekanizmasının bozulmasına yol açmaktadır.

İşsizliğe ve yoksulluğu yönelik sosyal hak temelli politikalar iki gruba ayrılabilir: İstihdam ve gelir garantisi. Gelir garantisi ya da temel gelir politikasının amacı, genel olarak bireyin gelirinin nedeni ne olursa olsun en temel ihtiyaçlarını karşılamak için gerekli düzeyin altına düşmesini önleyecek bir hükümet garantisi sağlamaktır (Tcherneva ve Wray, 2005 ve Tcherneva, 2003). Temel geliri savunanlara göre iktisadi adalet, özgürlük ve vatandaşlık, çalışmaya bağlı olmaksızın kaynakların ihtiyacı olan bireylere tahsisini savunmaktadır. Bu yaklaşıma 
göre emek piyasaları, artık insanların temel ihtiyaçlarını karşılayacak düzeyde ücret ödememektedir. Küresel gelişmeler, uzun işsizlik dönemleri ve yüksek enflasyon piyasanın atıl bulduğu insanları marjinalleştirmektedir. Vatandaşlık geliri, devlet yardımı gibi farklı isimlerle anılan temel gelir vatandaşların cinsiyetine, , rkına, çalışma statüsüne, medeni haline bakılmaksızın her vatandaşa genel bir ödemeyi taahhüt etmektedir. Temel gelir garantisinin varlığı, insanlara sosyal güvence sağlarken, aynı zamanda bireyleri özgürleştirmekte ve onların pazarlık güçlerini arttırmaktadır. Ayrica temel gelir garantisi, toplumdaki marjinallerin sosyal içermesini sağlamakta ve sosyo-ekonomik statüsünü arttırmaktadır. Bu tür gelir garantisi politikalarına en önemli eleştiri, yoksullara ve işsizlere yap1lacak sosyal yardımların tembelliği teşvik edeceği ve yoksulluk kültürüne neden olacağıdır (Gül, 2009:199).

İstihdam garantisi politikaları ise, özellikle işsiz ve yoksullara çalışma hakkını öngören politikalardır. Çalışmak istediği halde is bulamayanların istihdamını garanti ederek, tam istihdamı hedeflemektedir. İstihdam garantisi programlarınin temel özellikleri şunlardır ${ }^{1}$ :

* Özel sektörde iş bulamayan ve hükümetin belirlediği ücretten çalışmak isteyen herkesi istihdam eden, yani sıfır işsizlik oranını garanti eden bir programdır. Hükümet, özel sektörde iş bulamayan ve hükümetin belirlediği asgari ücretten çalışmak isteyen herkesi (niteliksiz-düz işçi) istihdam etmektedir. Hükümet özel sektörün talep etmediği fakat çalışmak isteyen işsizleri, önceden belirlenen sabit asgari ücretten istihdam etme teklifinde bulunmaktadır. Dolayısıyla hükümet istihdam piyasasında istihdamın fiyatını belirlerken, istihdam miktarını piyasaya bırakmaktadır.

* Hükümet niteliksiz işçinin ücretini asgari düzeyde belirleyerek özel sektör ücretlerinin, maliyetlerinin ve böylece fiyatlarının istikrarlı olmasına katkı sağlamaktadır. Böylece hükümetin sabit asgari ücretten istihdam ettiği kişilerden oluşan istihdam stoku, fiyat istikrarının sağlanmasına da yardımcı olmaktadir.

* Hükümetin istihdam stokundaki değişmeler, otomatik olarak bütçe açıklarını belirlemektedir. Hükümetin bütçe açıkları genelde ekonomik konjonktüre bağlıdır. Ekonominin durgun (planlanan tasarruflar, gerçekleşen tasarruflardan büyük) olduğu dönemlerde özel sektörde işsiz kalanlar, asgari ücretle devlette istihdam edilecekler ve böylece bütçe açıkları artacaktır. Ekonominin canlandığ 1 dönemde ise özel sektörün istihdam talebi artacak, hükümetin istihdam stokundan (önceden belirlemiş olduğu asgari ücretin üzerine koyduğu marjdan) işçi istihdam edecektir. Özel sektörün hükümetin istihdam stokunu azaltacak şekilde hareket etmesi, hükümetin bütçe açıklarını azaltacaktır.

* Bu programdaki işler, özel sektör tarafından arz edilmeyen işler olması nedeniyle özel sektördeki işlere ikame değildir. Genel olarak yaşlılara refakat, kamu okullarında sınıf asistanlığ 1 , yerel güvenlik hizmetleri, yoksul bölgelerde ev bakım-onarım işleri, çevre güvenliği hizmetleri, bu programdan yararlananlar için günlük çocuk bakımı ve sağlık hizmetleri asistanlığı, toplum ve kültür tarihçiliği gibi hizmetleri kapsamaktadır. Bu program özel sektörle tamamlayıcılık ilişkisi içindedir. Çünkü, devlet tarafından kamu sektöründe istihdam edilen işçilere, özel sektör ya da diğer kamuda çalışanların yaptıkları işlerin dışındaki işlerde çalışmaları için kapsamlı bir eğitim verilmektedir.

* Bu program, mevcut kamu sektörü istihdamının ikamesi değildir. Kamu sektöründe istihdamı garanti eden program dışında çok sayıda işler de bulunmaktadır. $\mathrm{Bu}$ işlerde çalışanlar istihdam garanti programinda istihdam edilenlerden daha yüksek ücret almaktadırlar.

\footnotetext{
1 Ayrıntılı bilgi için bkz. Minsky (1965 ve 1986); Wray (1988); Mosler (1997-98); Mosler ve Forsater (1999); Kregel (1999 ve 2006); Tcherneva (2003 ve2005a); Işık (2009a ve 2009b).
} 
İstihdamı garanti eden politikalar hem çalışmak isteyen herkesi istihdam ederek tam istihdamı garanti etmekte hem de özel sektör için önemli bir maliyet kalemini sabitleyerek ekonomide fiyat istikrarının sağlanmasına katkı sağlamaktadır. Özellikle yapılan alt yapı yatırımları, özel sektör yatırımlarını daha cazip hale getirmekte ve yat1rım maliyetlerini düşürmektedir. $\mathrm{Bu}$ programla ilgili en önemli eleştiriler parasal ücretin, kayıt-dışı sektördeki işçilerle aynı düzeyde olması, üretilen mal ve hizmetlerin kalitesinin düşük olması ve temel ihtiyaçları karşılamaya yönelik olması ve mali olarak sürdürülemezliğidir (Işık, 2009a). Bu politikaların özellikle gelişmekte olan ülkelerde uygulanmasıyla ilgili olarak şu olası sorunlarla karşılaşılmaktadır: Az sayıda mal ve hizmetin üretilmesi, ithalatın yüksek ihracatın düşük olması, hükümetlerin yönetsel kapasitelerinin düşük olması, kayıt-dışı piyasalar ile kayıtl1-resmi piyasalardaki ücretler arasındaki büyük farklılıklar, üretim kapasitesini arttırmak için yurtiçi alt-yap1 yatırımlarının yetersiz olması, sabit döviz kuru politikasi izlenmesi (Papadimitriou, 2009).

Temel gelir garantisi, birçok açıdan istihdamı garanti eden politika ile büyük benzerlik göstermekle birlikte, birçok açıdan ondan farklılaşmaktadır². Temel gelir garantisi çalışma zorunluluğu olmaksızın uygulanabilirken, istihdam garantisi doğrudan işsizliğe odaklanmaktadır. Yani çalışmak isteyen fakat is bulamayan insanları hedeflemektedir. Gelir hakkından ziyade çalışma hakkını savunmaktadır. Ancak, temel gelir politikası çok maliyetlidir ve çalışma hakkı için yeterli derecede vurgu yapmamaktadır. Diğer yandan iki politika önerisi de esas olarak iki bakımdan uzlaşmaktadır. Uzlaşılan noktalardan ilki, piyasa ekonomisinin insanların insanca yaşamasına yetecek gelirler elde etmesini engellemiş, sosyal korumayı azaltmış ve emek piyasasında riskleri artırmış olmasıdır. İkincisi ise bu sorunların varlığı nedeniyle tüm vatandaşları kapsayacak şekilde evrensel garantiler sağlamak için kamu politikalarına görev düștüğünün kabul edilmesidir. İki politika önerisiyle ilgili bir diğer önemli nokta, dikkatli uygulanmaları durumunda birbirlerine alternatif değil tamamlayıcı olduklarıdır. Örneğin yaşlı, hasta, genç gibi çalışabilir durumda olmayanlara temel gelir garantisi uygulanabileceği gibi belli bir hastalığ 1 olmayan ve çalışabilir durumda olanlara istihdam garantisi politikası uygulanabilir.

İstihdam garantisi politikası teorik olarak Knapp (1924) ve Lerner (1943)'in geliştirdiği "fonksiyonel maliye" ${ }^{3}$ yaklaşımına dayanmaktadır. Bu yaklaşımda devlet vatandaşlarına vergi koyar, bu verginin kendi ihraç ettiği para ile ödenmesini kabul eder ve vatandaşların bu parayı temin edecekleri koșulları belirler. Para, devlet harcama yaptığında yaratılmakta ve vergi koyduğunda ise piyasadan çekilmektedir. Devlet, piyasada aşırı para arzı olması durumunda bu parayı çekmek için borçlanacaktır. Hükümet harcamaları, vatandaş üzerine vergi konulması ve/veya kendi yarattığı paranın özel sektör tarafından talep edilmesiyle finanse edilmektedir. Devlet harcama yapmak için vatandaşın parasına ihtiyaç duymazken vatandaşlar, vergi yükümlülüklerini ödemek için devletin parasına ihtiyaç duymakta ve piyasaların yaninda devlete de mal satmak veya emeğini arz etmek zorunda kalmaktadır. Özel sektörün hükümete arz ettiği mal ve hizmetlerin miktarı (hükümet harcamalarına eşittir), hükümetin özel kesime koyduğu vergi miktarı tarafından belirlenmektedir. Hükümet harcamaları parasal tabanı artırırken, vergi ödemeleri parasal tabanı azaltmaktadır. Dolayısıyla, devletin vergi koymasının temel nedeni, parasal taban için talep yaratmaktır. Devlet para ihraç etme tekeline sahip olduğundan, harcamalarını vergilerle veya borçlanmayla finanse etmesi gerekmez. Bu yaklaşımda devlet önce parasal taban yaratacak şekilde harcama yapar ve daha sonra vergi toplar. Devlet parasal taban yaratmadan önce özel sektör vergi yükümlülüklerini yerine getiremeyeceğinden,

\footnotetext{
2 Daha ayrıntılı bilgi için bkz. Tcherneva (2003); Tcherneva ve Wray (2005).

3 Ayrıntılı bilgi için bkz. Işık (2009a ve 2009b).
} 
sürekli olarak açık vermek zorunda kalacaktır. Bu durumda hükümetin bütçe açığı vermesi normal bir durumdur.

Fonsiyonel maliye yaklaşımında bütçe açığı, özel sektörün planladığ1 pozitif nominal tasarruf ve işsizlik birbirleriyle ilişkilidir. Dışa açık bir ekonomide özel sektörün planladığ 1 pozitif nominal tasarruflar bütçe açığı ve/veya diş fazlayla, kapalı bir ekonomide ise bütçe açıklarıyla mümkündür. Hükümetin denk bütçe politikası izlemesi durumunda özel sektör tasarruf yapamayacağından ekonomide işsizlik ortaya çıkmaktadır. Oysa hükümetler bütçe açığ1 verip piyasaya para arz ederse, özel sektörün nominal tasarrufları artar. Dolayısıyla, hükümetin daha fazla harcama yapması özel sektörü uyararak, daha fazla gelire, harcamaya, istihdama ve daha az işsizliğe neden olacaktır. Aksi durumda ise hükümetin açık vermemesi, yani yeni para arz etmemesi işsizliğe neden olmaktadır. Bu yaklaşıma göre hükümetin para monopolü nedeniyle para arzı, işsizliği ortadan kaldırana ve böylece tam istihdamı sağlayana kadar artırılabilecektir. Dolayısıyla, ekonomide işsizliği ortadan kaldıracak ve tam istihdamı sağlayacak şekilde hükümetin açık vermesini önleyecek hiçbir gerçek finansal kısıt yoktur. Hükümet tam istihdamın ötesinde harcamalarını arttırması ve para arz etmesi durumunda ise enflasyona neden olacaktır. Böylece iyi tasarlanmış bir devlet istihdam garantisi politikasında açıklar, planlanan tasarrufları aşmayacaktır. Başka bir ifade ile bütçe açığı tam istihdamı sağlayacak kadar toplam talebi artıracaktır. Sonuçta istihdam garantisi politikaları, tıpkı diğer hükümet harcamalarının finanse edildiği gibi finanse edilmekte ve fonksiyonel maliye yaklaşımına dayanmaktadir.

\section{ISTIHDAM GARANTISI POLITIKASI: ULUSLARARASI DENEYIMLER}

İstihdam odaklı ya da istihdamı garanti eden programlar birçok ülke tarafından özellikle II. Dünya Savaşı sonrasında uygulanmıştır (Tablo 1). Geçmişte istihdam odaklı olarak hükümetlerin uyguladığı politikalara en önemli örnek ABD'de Roosevelt'in 1933-36 yılları arasında uyguladığ 1 New Deal Programı (Yeni Düzen)'dır. Program, ABD'de Büyük Bunalım döneminde ortaya çıkan talep yetersizliği ve artan ișsizlik nedeniyle geçici olarak özellikle alt-yapı yatırımlarını kapsayan bayındırlık ișlerine dayanmaktaydı. Özellikle 1937 y1lında enflasyon korkusu nedeniyle bu politikalardan vazgeçildi. Buna karşın bu deneyim, devletin nihai işveren olma rolünü oynayabileceğini, bu rolü yerine getirirken özel sektör ile rekabet içinde olmayan ve sosyal, ekonomik ve çevresel olarak yararlı mütevazi işlerin yaratılabileceğini gösterdi (Kabuab, 2007:4). Doğrudan istihdam yaratan politikalar, ABD dışında birçok ülke tarafından uygulanmıştır. $\mathrm{Bu}$ programları/politikaları uygulayan ülke deneyimleri Tablo 1'de verilmektedir. Özellikle 1970'li y1llardan sonra neoliberal politikaları nedeniyle işsizlik ve yoksullukla ilgili deneyimler ve politikalar çok büyük ölçüde rafa kaldırıldı.

Son yıllarda tam istihdama yönelik politikalar ILO, bağımsız düşünce kuruluşları gibi değişik kaynaklar tarafından gündeme getirilmiş ve neoliberal politikaları uygulayan ülkelerin bir kısmı karşılaştığ krizlerin yol açtı $\breve{g}_{1}$ işsizlik ve yoksullukla mücadele etmek için küçük ya da büyük ölçekli olmak üzere istihdamı güvenceye alan politikalar uygulamaya başlamıştır. Bu politikalar, hedeflediği iktisadi amaçlara göre farklılık arz etmektedir (Mitchell ve Muysken, 2008:255). Örneğin 2005 y1lında Hindistan'da çalışma hakkını temel olan "Ulusal Kırsal İstihdam Garantisi Programı", Doğu Asya finansal krizde Endonezya ve Kore acil ve geçici bayındırlık işleri programı ve 2002 krizi nedeniyle Arjantin Jefes Programını uygulamıştır (Papadimitriou, 2008:7-8 ve Antonopoulos, 2009). Benzer şekilde Bolivya (1986), Şili (1975-1987), Peru (1991), Güney Afrika (2004-devam ediyor) gibi ülkeler yapısal ayarlamaların etkilerini gidermek için sosyal fonlar programı geliştirmiştir. Özellikle 2000'li yılların başından beri uygulanan istihdam garantili politikaların deneyimlerinden ders ç-karmak için bu politikaları küçük ölçekli uygulayan Fransa ile daha büyük ölçekte uygulayan Arjantin, Hindistan, Güney Afrika gibi ülke deneyimleri incelenecektir. 


\section{Tablo 1}

Hükümetin İstihdam Yaratması: Uluslararası Deneyim (Seçilmiş Programlar)

\begin{tabular}{|c|c|c|}
\hline Ülke & Yil & Program tanımı \\
\hline Arjantin & 2002-devam ediyor & $\begin{array}{l}\text { Hane Halkı Reisine Ödeme (Jefes de Hogar): } 18 \text { yaş altındaki çocuklu ai- } \\
\text { lelere her hafta } 20 \text { saat çalışma hakkı vermektedir. }\end{array}$ \\
\hline Avustralya & $1940-1970$ & $\begin{array}{l}\text { Keynesyen Commonwealth İstihdam Servisi: Bu programla, 1990'larda } \\
\% 9 \text { olan işsizlik oranı, \%2'ye düşürmüştür. }\end{array}$ \\
\hline Bolivya & $1986-90$ & $\begin{array}{l}\text { Acil Sosyal Fon: Bu programla çalışanlar, büyük ölçüde bayındırlık ve } \\
\text { altyapıda hizmetlerinde kullanılmıştır. }\end{array}$ \\
\hline Botsvana & 1980-devam diyor & $\begin{array}{l}\text { Emek Temelli Destek Programı ve Emek Yoğun Kırsal Kamu Çalışmaları } \\
\text { (Bayındırlık İşleri) Programı. } \\
\end{array}$ \\
\hline Şili & $1975-1987$ & $\begin{array}{l}\text { Asgari İstihdam Programı: Bayındırlık işleri yoluyla işsizlikle mücadele } \\
\text { etmek ve istihdamı arttırmak amacıyla uygulanmıştır. }\end{array}$ \\
\hline Fransa & $\begin{array}{l}2005 \text { 'de pilot uygulamaya ge- } \\
\text { çildi }\end{array}$ & $\begin{array}{l}\text { İlk olarak Jacques Attali tarafından önerilen ve } 2005 \text { 'de } 6 \text { bölgede pilot } \\
\text { uygulaması ile başlayan ve halen ulusal düzeyde resmi olarak kabul edi- } \\
\text { len bir programdır. }\end{array}$ \\
\hline Gana & 1988-devam ediyor & $\begin{array}{l}\text { Uygulanan politikaların sosyal maliyetlerini azaltması amaçlayan ve } \\
\text { büyük ölçüde emek-yoğun kesimleri kapsayan bir plandır. }\end{array}$ \\
\hline Hindistan & 1972, 2005-devam ediyor & $\begin{array}{l}\text { Maharashta İstihdam Garantisi Planı (EGS) ve Ulusal Kırsal İstihdam Ga- } \\
\text { rantisi Yasası ( NREGA), kırsal hane halklarına } 100 \text { günlük istihdam ola- } \\
\text { nağı sağlayan ve bugün } 330 \text { eyalette uygulanması öngörülen programdır. }\end{array}$ \\
\hline Bangladeş & 1980'li ve1990'lı yıllar & $\begin{array}{l}\text { Bayındırlık İşleri Programları:1980'lerde çalışanlar için gıda yardımı ve } \\
\text { 1990'l1 yıllarda kırsal bakım-onarım programları şeklinde uygulanmıştır. }\end{array}$ \\
\hline Endonezya & 1998'de yeniden başlatıld1 & $\begin{array}{l}\text { Padat Kayra Programı: Güney Doğu Asya krizi sonucunda yoksulluğu } \\
\text { azaltmayı acil iş yaratma önlemlerini ve küçük ölçekli altyapı projelerini } \\
\text { kapsayan bir programdır. }\end{array}$ \\
\hline Kore & $1997-1998$ & $\begin{array}{l}\text { İşsizliği çözmeye yönelik Master Planı: Güney Doğu Asya krizini takiben } \\
\text { düşük nitelikli iş̧̧ilere yönelik olarak uygulanan acil bayındırlık işleri } \\
\text { programı. }\end{array}$ \\
\hline Meksika & 1995-devam ediyor & $\begin{array}{l}\text { Programa de Empleo Temporal: Sosyal ve üretken altyapı için büyük öl- } \\
\text { çüde niteliksiz işçilerin kullanarak toplumsal kalkınmayı sağlamayı } \\
\text { amaçlayan bir programdır. } 2000 \text { yılı itibariyle } 1 \text { milyona kişi bu program- } \\
\text { dan yararlanmıştır. }\end{array}$ \\
\hline Fas & 1961-devam ediyor & $\begin{array}{l}\text { The Promotion Nationale: Kırsal toplumun (Saharan ve South Eyaletleri) } \\
\text { kalkınmasına yönelik olarak uygulanan bir programdır. Günümüze } \\
\text { kadar (46 yıl) başarıyla uygulanmaktadır. }\end{array}$ \\
\hline Nepal & 1989 & Dhaulagiri Sulama Geliştirme Projesi \\
\hline Peru & $1991-95$ & $\begin{array}{l}\text { Bayındırlık İşleri Programı: Temel olarak kadın üzerine yoğunlaşan ve } \\
\text { yaklaşık } 500 \text { bin kişiyi istihdam eden bir kamu çalışma programıdır. }\end{array}$ \\
\hline Güney Afrika & 2004-devam ediyor & $\begin{array}{l}\text { Genişletilmiş Kamu Çalışma (Bayındırlık İşleri) Programı: Çevre, altyapı } \\
\text { ve sosyal sektörlerde iş yaratmayı artıracak şekilde sektörlere ait harca- } \\
\text { maların yönünü değiştirmeyi hedefleyen bir programdır. }\end{array}$ \\
\hline Sri Lanka & 1985-devam ediyor & $\begin{array}{l}\text { Ulusal Barınma Kalkınma Birim: Kentlerde barınma ve alt-yapıyı geliş- } \\
\text { tirmeyi hedefleyen bir programdır. }\end{array}$ \\
\hline İsveç & $1938-1970$ & $\begin{array}{l}\text { "Yatırımların sosyalleşmesi” üzerinde yoğunlaşmış ve gelir hakkından } \\
\text { daha ziyade çalışma hakkına vurgu yapmış refah devletine karşı alterna- } \\
\text { tif bir politika olarak uygulanmıştır. Bu program, 1980'lerin sonuna kadar } \\
\text { işsizlik oranları, \%3'un altına düşürmüştür. }\end{array}$ \\
\hline A.B.D & $1933-1936$ & $\begin{array}{l}\text { New Deal (Yeni Düzen) Bayındırlık İşleri Programları: Bayındırlık İşleri } \\
\text { İdaresi, Ulusal Gençlik İdaresi gibi. }\end{array}$ \\
\hline Zambia & 1991-devam ediyor & $\begin{array}{l}\text { Yoksulluğu hedefleyen ve mevcut altyapının sürdürülmesine odaklanan } \\
\text { mikro proje birimi uygulamaları. }\end{array}$ \\
\hline
\end{tabular}

Kaynak: Papadimitriou, D. (2008) “Promoting Equality Through an Employment of Last Resort Policy”, Levy Economics Institute of Bard College, Working Paper No: 545, 3) ve Papadimitriou, D. (2009), "During and After the Crises: Why Is an Employer of Last Resort Policy Needed?", Levy Institute 


\section{Fransa}

Bugün küçük ölçekli ve dolaylı olarak istihdam garantisi politikası uygulayan ülkelerden biri de Fransa'dır. Fransa, gelecek yıllarda istihdam oranını yükseltmek (\%70) ve işsizlik oranını düşürmek (\%5'in altına) için yaşam boyu öğrenme, sosyal diyalogu geliştirme, kamu istihdam hizmeti, mesleki geçiş sözleşmesi (professional transition contract, PTC) gibi önlemlerle istihdam politikasında reformlar yaptı (Chevalier, 2008 ve Artus, 2009). Bu önlemlerin içinde en ilgi çekici olanı mesleki geçiş sözleşmeleridir. Bu planının esası, istihdam piyasası dışında kalan aktif olarak iş arayan ya da becerilerini geliştirmeye yönelik eğitim-öğrenme faaliyetlerinde bulunan işi olmayan bireylerin bu girişimlerini, sosyal olarak yararlı bir faaliyet olarak tanımlamasına dayanmaktadır (Kaboub, 2007). İş arayan işsizler, kendilerinin ciddi iş arama gayretlerine karşın bir iş bulamadıkları için sosyal yardımlardan muaf tutulmak ve cezalandirılmak yerine bu faaliyetlerinden dolayı ödüllendirmeyi amaçlamaktadır.

1000 işçiden daha az işçi çalıştıran şirketlerden ekonomik nedenlerle işten ayrilanların yararlanmasina yönelik olan bu program, 24 Nisan 2006-31 Aralık 2009 dönemi için 12 aylık bir sözleşmeyi (iş arama, mesleki eğitim ve iş dönemlerini birleştirmektedir) ve 7 bölgeyi kapsamaktadır. Bu süre içinde işsizlere yapılacak ödeme, önceki işinden aldığ 1 brüt maaşının \%80'i kadardır. Mesleki Geçiş Sözleşmesi bünyesinde maaş alanlar, mesleki stajyer konumunda olmakta ve özel ya da kamu kurumlarında istihdam edilebilecektir. PTC, işsizlik sigortasını hak edip/etmeden bağımsız olarak iktisadi nedenlerle şirketlerin işten çıkardığ 1 tüm işçileri kapsamaktadır (Chevalier, 2008). PTC, bir yandan gelir ve istihdama geri dönüş aç1sından işçilere garanti verirken diğer yandan da şirketlerin esnekliğini arttırmaktadır. PTC, büyük ölçüde işsizlik sigortasından ve bu programdaki işçileri istihdam eden şirketler tarafından finanse edilmektedir. İhti- yaç olması durumunda geri kalan kısım, hükümet tarafından finanse edilmektedir. PTC, tahmin edilen toplam maliyeti Fransa gayri safi yurtiçi hasılasının yaklaşık \%4'üne tekabül etmektedir.

Mesleki geçiş sözleşmelerine dayanan bu plandan, Nisan 2006-Kasım 2008 döneminde 4200 kișiden daha fazla ișçi yararlanmıș, bunların yaklaşık \%31'i en az bir ișe yerleştirilmiş, \%47'si 36 saatten daha fazla mesleki eğitim almış ve yararlananların yaklaşık $\% 44$ 'ü daha uzun vadeli olarak iş değiştirmiştir (Chevalier, 2008). Bu programın maliyeti, Fransa'da bugün işsizlik sigortası ve diğer istihdam programlarına harcanan GSYİH'nin \%4.2'sinden daha azdır (Kaboub, 2007). PTC, 2008 küresel krizi ile birlikte daha geniş bir programa dönüşmüştür.

\section{Arjantin}

Arjantin'de ekonomik krizin yol açtığ1 sosyal ve siyasal istikrarsızlığı gidermek için acilen Nisan 2002'de Jefes Planı (Jefes de Hogar-Aile Reisleri) ${ }^{4}$ uygulanmaya başlandı . Jefes Planı, özellikle 18 yaş altında çocuk, özürlü kişi veya hamile kadını olan yoksul aile reislerine iş sağlamayı hedeflemekteydi (Tepepa, 2009). Ayrıca, plandan yararlanmak için aile reislerinin çocuklarını okula kaydettirmesi ve aşılatması şartları getirilmiştir. $\mathrm{Bu}$ özellikleri sağlayan aile reisine, günlük asgari 4 saat (haftada 20 saat) çalışması karşılığında aylık olarak 150 peso (50\$) ödeme yapılması öngörülmüştür. Aylık yoksulluk sınırının 300 peso (100\$) olduğu düşünüldüğünde, parttime iş için yoksulluk sınırının yarısı ödenmekteydi. Bu plana katılan aile reisleri ya inşaat, tarım, bakım- onarım gibi işlerde çalışmakta ya da eğitim kurslarına (temel eğitimi bitirmek dahil) yönlendirilmekteydiler. Ayrıca program aile reislerinin, kamuda çalışılan dört saat dişında diğer işlerde de çalışmak amacıyla iş araştırmalarına imkan sağlamaktaydı.

Jefes Planı'nın finansmanının tamamının Arjantin'in kendi kaynaklarından karşılanması öngörülmüştür. Bu programın uygu-

\footnotetext{
4 Daha detaylı bilgi için bkz. Işık (2009a ve 2009b); Tepepa (2009); Levy Insitute (2009).
} 
lanması için gerekli tüm altyapı (ekipman maliyetleri, çalışma projelerinin yürütülmesi için genel yönergelerin hazırlanması, bazı destek hizmetleri gibi) maliyetleri hükümet tarafından karşılamıştır. Çalışma Bakanlığı'nın yürüttüğü bu Plan, ademi merkeziyetçi bir yaklaşımla yerel yönetimler tarafından uygulanmaktadır. Bu planla ilgili olarak belediyelerin görevi, kendi vatandaşlarının acil ihtiyaçlarını ve mevcut kaynakları tespit etmek ve kar amacı gütmeyen yerelsivil toplum kuruluşlarının önerdiği projeleri değerlendirmek şeklinde belirlenmiştir. Kabul edilen projeler için belediyeler, programdan yararlananlarla sözleşme imzalayarak, işin mevcudiyeti, zamanı ve yeri hakkında onları bilgilendirmektedir. Programda istihdam edilenlerin yaklaş1k \%10'u gönüllü toplum kuruluşları tarafından organize edilen ve yürütülen projelerde çalışmaktadır. Jefes Planı'na göre, federal hükümet, her bir projenin maliyetinin en fazla \%80'ini karşılamaktadır. Projelerin geri kalan kısmı, yerel belediyeler ve kar amacı gütmeyen $\mathrm{ku}$ rumlar tarafından finanse edilmektedir.

Jefes Planı'ndan yararlananların yaklaşık $\% 90$ '1 tarımsal mikro girişimler ile çeşitli sosyal hizmetleri kapsayan toplum projelerinde çalışmaktadır (Tepepa, 2009). Kırsal programlar, genel olarak tarım sektöründe temizlik ve kanalizasyon sistemleri gibi çevresel destekleri kapsamaktadır. Toplum projelerinin büyük bir kismi, mevcut yerel toplum merkezlerinin yenilenmesi veya yeni merkezlerin alt yapı çalışmalarından oluşmaktadir. Bu merkezlerdeki toplum hizmetleri genel olarak aşevlerini, şiddete maruz kalanlar için geçici barınma merkezlerini, tacize uğrayan kadınlara ve kimsesiz çocuklara yönelik merkezleri kapsamaktadır. Sağlıklı yaşam ve temel sağlik problemlerini gidermeye yönelik, eğitimi kapsayan sağlığı geliştirmeye yönelik projeler ve ayrica yoksul bölgelerde, kamu kütüphanelerinde çalışmayı öngören projeler de bulunmaktadır. Yine Arjantin İmar Bankası'nın yürüttüğü yol, baraj gibi büyük altyapı çalışmalarında Jefes katılımcılarının çalıştırılması gibi işler de bulunmaktadır. Bazı projeler ise büyük marketlerde Jefes çalıșanlarının el emeğiyle ürettiklerini satması için yer tahsis etmeyi; ekmek gibi temel ihtiyaç mallarının yoksul komşulara dağıtılmasında görev almayı öngörmektedir. Yine bazı Jefes çalışanları, hükümetle kontrat yaparak okul giysileri sağlama gibi hizmetleri üretmek için işbirliği yapmakta, günlük 4 saat için maaş almanın yanı sıra arta kalan zamanlarda isteğe bağlı olarak çalışmaları durumunda elde edecekleri gelirleri kendi aralarında paylaşmaktadırlar. Ayrıca Jefes çalışanlarına başka ek faydalar da sağlanmaktadır. Çoğu Jefes projeleri, bu işlerde çalışan özellikle küçük çocuk sahibi annelere yönelik olarak gönüllü çocuk bakımı hizmeti vermektedir. Anneler, evlerine yakın yerlerde çalışabilmekte ve çalıştıkları yerde sağlanan sosyal hizmetlerden de yararlanabilmektedir.

Jefes Planı uygulama sonuçları, düşük ücret ödemesine ve programların yürütülmesi ile ilgili bazı sorunlara (yanlış yönetim, kayırma gibi) karşın, hane halkının gelirlerini arttırdığını göstermektedir. Bu Planı ile Arjantin'de hane halklarının ortalama geliri artmış ve yoksulluk sınırındaki hane halkı oranı 2003 'de \%42.6'dan 2006'da \%19.2'ye düşmüştür (Levy Institute, 2009). Kisa bir süre içinde yaklaşık olarak nüfusun $\% 5$ 'ine ve işgücünün \%13'üne yani 2 milyon kişiye iş sağlamıştır. Diğer yandan bu plan için yapılan maksimum harcama, Arjantin'in gayri safi milli hasılasının yaklaşık olarak \%1'i ve Federal bütçenin ise $\% 4.9^{\prime}$ una tekabül etmektedir. Jefes Planı çarpan etkisi de dikkat alındığında, toplam talebe yaptığı katkıyla gayri safi milli hasılayı yaklaşık olarak \%2.5 arttırmıştır. Arjantin deneyimi, bütün zorluklara karşın iş ve istihdam yaratmada başarılı olunabileceğini göstermektedir. İşsizlere ve yoksullara, sadaka değil, çalışma fırsatı sunulmuş, sosyal güvence sağlanmış ve sosyal bir hak olarak çalışma hakkının önemi vurgulanmıştır.

\section{Hindistan $^{5}$}

Hindistan, 40 yıllık Maharashta İstihdam

\footnotetext{
5 Bu alt bölüm büyük ölçüde Işık (2009a ve 2009b)'e dayanmaktadır
} 
Garantisi Planı (EGS)'nın deneyimlerini dikkate alarak yüksek işsizlik ve kırsal kesimdeki yoksullukla mücadele etmek için Eylül 2005'te "Ulusal Kırsal İstihdam Garantisi Yasası (NREGA)"nı kabul etmiştir. Yasa, kırsal ve yoksul bölgelerde yaşayan her aileye kırsal kamu çalışma projelerinde her yıl 100 iş günü çalışmayı ve minimum bir ücret ödenmesini; kamu işlerinde niteliksiz işgücünün istihdam edilmesini garanti etmektedir. Program, iş başvurularını izleyen 15 gün içinde iş sağlanmasını öngörmektedir. Bu süre içinde iş sağlanamazsa, asgari ücretin en az 1/3'üne tekabül edecek şekilde günlük isssizlik ödemesi yapılması garanti edilmektedir. Bu program kırsal bölgelerde yaşayan her aileden 18 yaş üzerinde bir kişiye bu olanağ1 sağlamayı hedeflemiştir.

Hükümeti, bu olanağ 1 çıkardığ 1 yasayla başlangıçta en yoksul 200, daha sonra 330 ve nihayetinde tüm diğer yoksul-kırsal eyaletlere (bölgelere) yaygınlaştırmayı öngörmektedir. NREGA'nın öngördüğ̈̈ program, daha çok çevrenin korunması ve restorasyonu (su gözetimi, toprağın yeniden kullanilır hale getirilmesi, toprak erozyonunun önlenmesi, su depolarının restorasyonu) gibi emek yoğun işlere dayanmaktadır. Bu yasa, mevcut ulusal koalisyon hükümeti tarafından, kırsal Hindistan'ın yapısal dönüşümünü sağlayacak ve böylece yoksulluğu azaltacak radikal bir program olarak tanımlanmaktadır. Bu programin kırsal kesimde alt yapının tesis edilmesi ve büyümenin arttırılmasıyla, yoksulluk üzerinde büyük bir etki yapacağı öngörülmektedir. Programın en önemli özelliği yasayla çalışma hakkının bir sosyal hak olarak kabul edilmiş olmasıdır. Bu programla kırsal yoksulluğun önemli ölçüde azaltılması, kırsal bölgelerde sosyal güvenlik sisteminin oluşturulması, sosyal eşitliğin geliştirilmesi, kırsal emek gücünün güçlendirilmesi, toprağın verimliliğinin artırılması, çevresel koşulların iyileştirilmesi gibi amaçlara hizmet edilmesi hedeflenmektedir. Bu yeni istihdam garantisi programi, ülkenin kırsal bölgelerindeki milyonlarca yoksula zorunlu ihtiyaçlarını karşılayacak şekilde bir yaşam düzeyi öngörmektedir. Hindistan'da böyle bir sosyal güvence hakkı (çalışma hakkının temel yasal bir hak olarak benimsenmesi) ülke yoksulları için radikal bir yaklaşım ortaya koymaktadır.

Bugün NREGA ilk beş yıllık aşamasını tamamlamış; diğer tüm yoksul-kırsal bölgelere uygulanmaktadir. $\mathrm{Bu}$ programin uygulama sonuçları şöyle özetlenebilir (Chakraborty, 2009): 45 milyon hane halkına iş yaratıldı. Programin mali yüküne gelince Ulusal koalisyon hükümeti NREGA programı için 2006-2007 mali yılında ulusal bütçeden 2.5 milyar dolar ayrılmıştır. Bu bütçenin toplam hükümet harcamalarına oran1 \%1.2, GSYİH'ya oran1 \%0.2'dir. 20072008 döneminde ise NREGA bütçesinin hükümet harcamasına oranı \%1.5 ve GSYİH'ya oranı ise $\% 0.27$ düzeyindedir. Bu dönemde, 2006-2007 dönemine göre NREGA'ya ayr1lan kaynaklardaki artış yaklaşık \%47'dir. 2008-2009 dönemi için tahsis edilen bütçe ise hükümet harcamalarının \%2.7'si düzeyindedir ve GSYİH'ya oranı ise yaklaşık olarak $\% 0.5$ düzeyindedir. Bu dönemde bir önceki döneme göre NREGA'ya ayrılan kaynaklardaki artış ise \%137 düzeyindedir. Sonuçta NREGA programı sayesinde kırsal bölgelerde işsizlik ve yoksullukla mücadelede büyük başarı kazanılmıştır. Özellikle bu programın mali yükünün sürdürülebilir olması nedeniyle kırsal bölgeler yanında kentsel bölgelerde de uygulanabilirliği yaygın olarak kabul edilmektedir.

Sonuç olarak her ne kadar NREGA, bütçeye getireceği yükler, eğitimin yetersizliği, yaratılan işlerden zenginlerin daha fazla yararlanacağı, yaratılan işlerin kalitesi ve sürdürülebilirliği, şeffaflık, ahbap-çavuş ilişkisi gibi eleştirilere maruz kalsa da bu sorunların, çok iyi tasarlanmış yönetsel-teknik kapasitenin geliştirilmesi ve istihdama yönelik gelişmiş meslek edindirme faaliyetlerinin arttırılmasıyla aşılabilesi mümkündür.

\section{Güney Afrika}

Güney Afrika, 2000'li yılların ilk yar1sında yaklaşık olarak \%25-30 düzeyindeki kronik işsizlik nedeniyle 2004 yıllında diğer önlemlerle birlikte "Genişletilmiş Bayındırlık İşleri Programı" (GBIP) nı yürürlüğe koy- 
muştur. Bu programının temel amacı işsizlere kısa-orta dönemde mesleki eğitim yoluyla yeteneklerini geliştirmek ve böylece ek istihdam fırsatları yaratmaktır. Program, çoğunlukla hiçbir yeteneği olmayan kişilere devletin daha fazla istihdam firsatı yaratmasinı hedeflemektedir. Bu program, beş y1l içinde bir milyon iş yaratma (yararlananların en az \%40'1 kadın, \%30'u genç ve \%2'si özürlü olacak) hedefiyle, işsizlere maaş karşılığı iş yaratmayı öngörmektedir. Bu programin temel amac1, iş (istihdam) yaratma yoluyla işsizleri ekonomik olarak güçlendirmektir (Antonopoulos, 2009:2). Bu programdaki projelerin büyük bir kısmı inşaat ve bakım-onarım gibi emek-yoğun alt yapı yatırımlarına dayanmaktadır. Bu program, genel olarak kısa dönemde zor olmakla birlikte, küçük bütçe tahsisi ile daha derinden dönüştürme/değiştirme hedefleri belirlemektedir ${ }^{6}$. Bu projelerde çalışanları diğer işlere yönelecek şekilde gelir ve meslek edindirmenin sağlanması bu programın öncelikli amaçları arasındadır.

Bu programda iş fırsatları, temel olarak 4 bölüme ayrılmaktadır: Alt yapı sektörü, çevre sektörü, sosyal sektör ve ekonomik sektör. Alt-yapı ve bakım onarım sektörü, öncelikle işsizlerin bu alanda eğitimden geçirilmesi ve yetenek kazandırılmasını kapsamaktadır. Alt-yapı ve bakım onarım sektörü yollar, su tedariki, temizlik işleri, okul, park gibi kamusal alanları kapsamaktadır. Bu sektörde çalışan işsizlerin bu alanda eğitimden geçirilmesi ve yetenek kazandırılmasını kapsamaktadır. Çevre sektörü su çalışmaları, itfaiye çalışmaları, çevreyi yeşillendirme, orman bakımı, kıyıturizm bölgelerinin temizliği, toprak geliştirme gibi her türlü çevreyle ilgili işleri; sosyal sektör, özellikle erken çocuk bakımı, yaşlı bakımı, ev bakımı gibi sağlık ve bakım işlerini; ekonomik sektör, küçük işletmeleri ve kooperatifleri geliştirecek şekilde girişimciliği artıracak her türlü programı kapsamaktadir. Bu program, bu dört sektörün her birindeki sektörel koordinasyon bölümü tarafından yönetilmektedir. Bayındırlık İşleri Bölümü, hem genel bir GBİP koordinasyon bölümü hem de alt-yapı bölümü için sektörel koordinasyon bölümüdür. İşgücü Bölümü ise, bu programda çalışanların mesleki/eğitim giderlerini karşılamakta ve sektörlerin koordinasyon bölümlerinin temsilcilerinden oluşan bu GBİP mesleki eğitim komisyonunu koordine etmektedir. Sektör temscilcileri her ay toplanır. Tüm iller, kendi GBIPP yönetim kurullarını da oluştururlar. Diğer yandan Bayındırlık İşler Bölümündeki genel GBİP koordinasyon bölümü ise denetleme ve değerlendirmeden, hükümete rapor hazırlamadan, sektörler arasında ilişkileri geliştirmeden sorumludur. GBİ, finansal olarak sadece işsizlik ve yoksullukla mücadele etmek için tasarlanmış bu programı, ulusal bütçeden yaptığı tahsisle finanse etmektedir.

Güney Afrika'da bu programin 2004 y1lında bir milyon iş fırsatı yaratma hedefi, 2008 yılında öngörülenden daha önce aşılmiştır. 2004-2008 döneminde GBİP programindaki tüm harcamalar (alt yapı bağış bütçeleri olan 2.8 milyar dolar hariç) 1.68 milyar dolardır (Kie-Song, 2009). GBİP programı üzerindeki bu harcamaların gayri safi yurtiçi hasılaya oranı $\% 0.7$ düzeyindedir. Bu harcamaların hükümet bütçesine oranı ise \%2.4 düzeyindedir. Dolayısıyla, program bütçesi önemli fakat yeterli değildir. GBİP bu dönemde 440.246 iş yaratmıştır. Bu programın yarattığ 1 iş fırsatlarının resmi işsizliğe oran 1 ise \%11'dir. Programdan yararlananların profiline bakıldığında ise yararlananların \%54'ü erkek, \%46'sı kadındır. Bu program öncesinde hane halkı geliri 50 ile 90 dolar arasinda iken bu programdan sonra hane halkı geliri 90 ile 120 dolar arasında gerçekleşmiştir. Yararlananların yaklaşık yarıs1, hane halkı reisidir.

Bu programin yukarıdaki olumlu yanlarına karşın programla ilgili olarak birçok eleştiri bulunmaktadır (Kie-Song, 2009). Eldeki bütçe tahsisatı ile mevcut kronik işsizlik/yoksulluk problemini çözmenin

\footnotetext{
6 Ayrıntılı bilgi için bkz. http://www.epwp.gov.za/index.asp?c=Welcome, Public Works, Republic of South Africa
} 
zorluğu, istihdam fırsatlarının kısalığı, mesleki eğimin hedefleri ve amaçları gerçekleștirme zorluğu, farklı ücret yapıları ve istihdam koşullarının yarattığ zorlukları (ücret farklılığı sorunu, kamu sektörü/resmi/gayri resmi/sürekli/geçici istihdam gibi sosyal sektörün kurumsal problemleri) bu eleştirilerden birkaçıdır. Programı gerçekleştiren kurumların kapasitesinin sınırlı olması, teknik desteğin yetersizliği ve kapasite yaratma yeteneğinin yeterince önemsenmemesi diğer sorunlardır. Yine programla ilgili bir diğer ihtiyatlı eleştiri ise kısa dönemde önemli başarılar elde etmek zor görünmektedir. Sonuçta yeni kamu/bayındırlık çalışmalarının çalışıp/çalışmayacağı üzerinde şüpheler bulunmaktadir. Programin ilk safhasındaki deneyimler özellikle kurumsal zorluklara işaret etmektedir.

GBIP'in birinci safhas1, bu programin yaygınlaştırılması için potansiyel yarattı. Hükümet, bu programin birinci safhasinın (2004-2008 dönemi) başarısından sonra ikinci safhasına (2009-2014) geçmeyi planlamaktadır. Hükümet bu amaçla iller, belediyeler ve hükümetin desteklediği sivil toplum kurumlarında daha uzun süreli ve daha istikrarlı istihdam yaratmak için program bütçesini büyük ölçüde artırmıştır. $\mathrm{Bu}$ ikinci safhada amaç bu dönemde 4,5 milyon is fırsatı yaratmaktır (Kie-Song, 2009). Programın ikinci safhası birçok yeni özelliğe sahiptir ${ }^{7}$. Illki, eyalet ve belediyeler, hedeflere (kadın, genç ve özürlüler için minimum katılımcı hedefine) ulaşması ve hatta aşması durumunda ödüllendirilecektir. İkincisi, iş yaratmada, sivil toplum daha fazla rol üstlenecektir. Üçüncüsü, çalışma için gerekli mesleki eğitimler üzerinde yoğunlaşılacaktır. Dördüncüsü, her iş fırsatında ortalama süreyi 100 güne çıkarmaktır. Beşincisi, mümkün olduğu kadar faaliyetlerin büyük bir kısmının ulusal asgari ücretin uygulanması, tam zamanlı çalışanlara yoksulluk sınırı üze- rinde ödeme yapılması ve mevcut yasal asgari ücretin așılmamasıdır. GBİP'ında her gün çalışma karșıllığında önerilen ücret, günlük 6 dolardır. Altıncısı, programı geliştirmek ve çalışma süresini arttırmak için devlette uygulama birimleri arasında ücret teşviki yapılması. Hükümet, sivil toplum kuruluşlarının yöneteceği projeleri büyük ölçüde kendisi finanse edecektir. GBİP, yoksulluğa karşı mücadelenin entegre bir parçası olarak iş yaratma ve yeteneklerin geliştirilmesini arttırmak için kamu fonlarını kullanan bir devlet inisiyatifidir. Nihayetinde bu programın öngördüğü iş fırsatları, mevcut sürekli işlerin yerini almaktan ziyade farklı ve gerçek hizmet talebini karşılamayı amaçlayan işlerdir.

Genel olarak değerlendirdiğinde yoksulluk ve işsizlikle mücadeleye yönelik büyük ölçekli ve doğrudan istihdam yaratan programları uygulayan Arjantin, Hindistan ve Güney Afrika gibi ülke deneyimlerinin temel özelliği, neoliberal politikalara karşı alternatif bir yaklaşım geliştirmiş olmasıdır. Bu yaklaşımda istihdamin yaratılması ve geliştirilmesinde devlete önemli rol düşmektedir. Bu deneyimlerin ortak özelliği, işsizlik ve yoksullukla mücadelede sistemin kurbanları yerine istihdam firsatları yaratmak üzerine yoğunlaşmasıdır. Ülke deneyimleri, istihdam garantisi politikalarının mali olarak uygulanabilir olduğunu göstermektedir. Ayrıca istihdamı garanti eden politikaların maliyeti üzerine yapılan bilimsel çalışmalar ${ }^{8}$ da bu yaklaşımı destekler mahiyettedir. Bu çalışmalarda GSYİH'nın bir oranı olarak ABD için \%1, Avusturalya için \%3.5, Güney Afrika için \%1.1, Tunus için \%2.72 (6 y1l için), Arjantin için \%1, Hindistan için \%0.2, Fransa için \%4.2 ve Brezilya için \%1.5'lik bir maliyet öngörülmektedir. Ülke deneyimleri ve bilimsel çalışmalar, istihdam garantisi sağlayan politikaların mali yükünü GSYİH'nın yaklaşık olarak \%1-3.5 arasında tahmin etmektedir. Program maliyetinin hesaplanma-

\footnotetext{
7 Ayrıntı bilgi için bkz. http://www.info.gov.za/speeches/2009/09040614451002.htm, South Africa Goverment Online.

8 Mitchell and Watts (1997); Gordon ( 1997); Wray (2007); Kaboub ( 2007a ve 2007b); Antonopouls (2009); Assis (2009).
} 
sinda uygulanan politikaların yeni işe alınanların gelirleri ve artan talepten kaynaklanan çarpan etkileri de dikkate alındığında bu politikaların potansiyel yararları, programin bütçesi ve ödenen ücretlerin çok ötesine geçmektedir (Papadimitriou, 2008:5). Diğer yandan bu politikaların uygulanmasıyla çalışanların sağlık koşulları iyileşecek, eğitim düzeyleri yükselecek, suç ve güvenlik harcamaları gibi sosyal maliyetler de azalacaktır. Oysa 1970'lerden günümüze ana akım iktisat ideolojisi, gittikçe güçlenen sermaye kesiminden aldığ 1 güçle sosyal hak temelli politikaların uygulanmasını engellemektedir. Sosyal hak temelli politikaların varlığ piyasa ekonomisinden geri dönüş olarak sunulmakta ve bu yönde kamuoyu oluşturulmaktadır. Sonuç olarak, özellikle gelişmiş ülkelerde bu politikalar ile ilgili temel sorun, iktisadi maliyetinden daha ziyade siyasi iradedir.

\section{ANTALYA ÖRNEĞİ}

Türkiye'de Eylül 2010 itibariyle resmi işsiz sayısı yaklaşık 2.9 milyon ve işsizlik oranı ise \%11.4 düzeyindedir 9 . Fertlerin \% 17.11 yoksulluk sınırının (gıda ve gida dişı harcamaları içeren) altında yaşamaktadır (TÜİK, 2009). T.C. Anayasası'nin 60. Maddesinde sosyal devlet olmanın bir gereği olarak herkesin sosyal güvenlik hakkına sahip olduğu ve devletin bu güvenliği sağlayacak gerekli tedbirleri almakla yükümlü olduğu belirtilmekle birlikte bugün yüksek işsizlik ve yoksulluğa karşı henüz geliştirilmiş kapsamlı bir politika önlemi/önlemleri bulunmamaktadir

Türkiye'de işsizliğe yönelik olarak işsizlik sigortası, İŞKUR tarafından yürütülen meslek eğitim faaliyetleri, aktif işgücü prog- ramları gibi önlemler uygulanmaktadır. Bunların dışında bugünkü küresel kriz nedeniyle istihdam piyasasına (işsizliğe) yönelik olarak iki geçici yasa çıkarmıştır. İlki, 5763 sayılı "İş Kanunu ve Bazı Kanunlarda Değişiklik Yapılması Hakkında Kanun"la işveren priminin 5 yil boyunca belirli oranlarda Hazine ve 18-29 yaş arasında hiçbir şart aranmaksızın işe alınan gençler ile tüm kadınların işveren primlerinin İşsizlik Sigortası Fonu tarafından ödenmesi hükme bağlanmıştır ${ }^{10}$. Diğer yandan, işsizlik sigortası fonunun işten çıkarılan işçileri korumaya yönelik olduğu ve işten çıkarılan sigortalı işçilerin büyük çoğunluğunun bu haktan yararlanmadıkları dikkate alındığında, bu fonun kullanılmasının sakıncalı yönleri olduğu açıktır. İkincisi, hükümetin kamuya yararlı işlerde çalışmak üzere 100-150 bin kişiye geçici olarak 6 ay için 300-600 TL aral1ğında maaş karşılığ 1 iş olanağı sağlayacak şekilde yapılan düzenlemedir. Geçici de olsa küresel kriz nedeniyle yurtdışı ve yurtiçi talebin ve dolayısıyla büyüme oranın düştüğü günümüz koşullarında bu önemler olumlu bir adım olarak değerlendirilebilir.

Nüfusun yaklaşık olarak beşte birinin yoksul olduğu Türkiye'de yoksullukla ilgili olarak sınırlı da olsa iki politika önlemi bulunmaktadır. İlki, 1976 yılından bu yana uygulanan 65 yaş üzerinde bakıma muhtaç olanlara ve özürlülere aylık bağlanması; ikincisi ise 1986 y1lında kurulan Sosyal Yardımlaşma ve Dayanışmayı Teşvik Fonu (SYDTF) tarafından yoksullara yönelik sosyal yardım fonlarıdır. SYDTF, ekonomik ve sosyal yoksunluk içinde bulunan vatandaşlarımızın gida, giyim, yakacak, barınma, sağlık, eğitim vb. acil ve güncel zaruri ihtiyaçlarını karşılamak amacıyla kaynak aktar-

9 TÜİK'nun işsizlik oranı hesaplamalarında işsiz olup fakat iş arama ümidini kaybeden işsizlerin hesaba katılmadığı dikkate alındığında işsizlik oranının geniş anlamda çok daha yüksek olacağı açıktır.

10 GEÇİCI MADDE 7'ye göre "18 yaşından büyük ve 29 yaşından küçük olanlar ile yaş şartı aranmaksızın 18 yaşından büyük kadınlardan; bu maddenin yürürlük tarihinden önceki altı aylık dönemde prim ve hizmet belgelerinde kayıtlı sigortalılar dışında olması şartıyla, bu maddenin yürürlük tarihinden önceki bir yıllık dönemde işyerine ait prim ve hizmet belgelerinde bildirilen ortalama sigortalı sayısına ilave olarak bu maddenin yürürlük tarihinden itibaren bir yıl içinde işe alınan ve fiilen çalıştırılanlar için; 506 sayılı Kanunun 72. ve 73. maddelerinde sayılan ve 78 inci maddesi uyarınca belirlenen prime esas kazanç alt sınırı üzerinden hesaplanan sigorta primine ait işveren hisselerinin; a) Birinci yıl için yüzde yüzü, b) İkinci yıl için yüzde sekseni, c) Üçüncü yıl için yüzde altmışı, d) Dördüncü yıl için yüzde kırkı, e) Beşinci yıl için yüzde yirmisi, İşsizlik Sigortası Fonundan karşılanır". 
maktadır. SYDTF'nun sosyal yardım amacıyla 2008 yılında aktardığı kaynak, 1,25 milyar TL'dir. Sosyal yardımların GSYİH'ya oranı ise \%0.13'dür. Yoksulluk sınırı altında kalan fert ve hane halkı sayısı dikkate alındığında bu oran oldukça düşüktür. Sosyal yardımlara ayrılan kaynakların ve kurumların yetersiz olması yanında yardımların oldukça keyfi ve düzensiz olarak dağıtılması da bir diğer önemli sorundur. Yapılması gereken yardımı, sosyal hak olarak kabul ederek iyi tanımlanmış kriterlere göre dağıtmak ve daha kapsamlı ve daha sistematik bir sosyal yardım politikası uygulamaktır (Buğra ve Sinmazdenir, 2007:99). Üstelik, sosyal yardımların nakit gelir desteği gibi daha sistematik bir politika ile uygulanması durumunda maliyetler beklenenden daha düşüktür. Buğra ve Sinmazdenir (2007) Türkiye'de yoksullukla mücadelede nakit gelir desteği uygulanması durumunda maliyetlerin GSMH'ye oranının \%0.56 ve bütçe giderlerine oranın ise \%0.89 olduğunu ileri sürmektedir ${ }^{11}$.

\subsection{Sosyal Yardımlar ve Gelir Dă̆ılımı İstatistikleri}

Antalya'da yoksulluğun ölçülmesi ve po- litika önerilerine geçmeden önce SYDTF, belediyeler (merkez ilçe belediyelerin) ve sivil toplum kuruluşları vasitasıyla Antalya'ya yapilan sosyal yardimların boyutunu ve kentteki gelir dağılımını tespit etmek önemlidir. Sosyal yardım miktarlarının derlenmesinde büyük ölçüde ilgili birimlerin raporlarından yararlanılmıştır. Sosyal yardımların miktarı konusunda kısmen de olsa bilgilere ulaşılmasına karşın, bu sosyal yardımların yararlananları hakkındaki bilgilere ulaşılamamıştır. Antalya'ya yoksulluk ve işsizlikle mücadele kapsamında yapılan yardımlar incelendiğinde SYDTF tarafından 2008 yılında aktarılan kaynak miktarı yaklaşık olarak 19,4 milyon TL'dir (Tablo 2). Merkez belediyelerin (Büyükşehir, Muratpaşa, Kepez, Konyaaltı) sosyal yardımlar için aktardığ 1 kaynakların toplamı 6,8 milyon TL; hayır kurumları ve sivil toplum kuruluşlarınin (gelirleri 10000 TL'nin üzerinde olan yaklaşık 30 dernek ve vakfın) sosyal yardimlar için kaynak transferleri ise 2,8 milyon TL'dir. Dolayısıyla, Antalya'da toplam sosyal yardım miktarı 29 milyon TL'dir. Antalya'da toplam sosyal yardımların Antalya GSMH'ye oranı \%0.12 düzeyindedir. Merkez belediyelerin sosyal yardımlarının büt-

\section{Tablo 2}

Antalya Sydtf'den Syd Vakıflarına Sosyal Yardım Programları Kapsamında Aktarılan Kaynaklar (2008), TL

\begin{tabular}{|l|r|}
\hline Periyodik Transfer & $5.309 .100,00$ \\
\hline Sermaye Transferi (bina bakımı) & $250.000,00$ \\
\hline Sağlık Transferi & $111.254,00$ \\
\hline Özürlü Destek Transferi & $10.240,00$ \\
\hline Mesleki Eğitim ve İstihdama Yönelik Projelere Transferler & $52.620,00$ \\
\hline Eğitim Transferi & $2.990 .782,00$ \\
\hline Aile Destek Transferi (glda, barınma ve yakacak) & $4.023 .260,00$ \\
\hline Sosyal ve Özel Amaçlı Transferler & $540.025,00$ \\
\hline Vakıflara Diğer Transferler & $45.000,00$ \\
\hline Dönüşümlü (Kasdep ve Gelir Getirici) Projeler & $6.047535,84$ \\
\hline Toplam & $\mathbf{1 9 . 3 7 9 . 8 1 6 , 8 4}$ \\
\hline
\end{tabular}

\footnotetext{
${ }^{11}$ Buğra ve Sınmazdenir (2007)'in yaptı̆̆ 1 çalışmada bu hesaplamalar, \%14 yoksulluk oranı kapsamında 1.720.208 haneye aylık yaklaşık 100 TL ödeme yapılmasına dayanmaktadır.
} 
çelerine oranı ise yaklaşık olarak \%1-1.5 aralığındadır. Sosyal yardımlarla ilgili oranlar, oldukça yetersiz düzeydedir.

Antalya'da sosyal hak temelli istihdam garantisi ya da gelir garantisi stratejilerinin olası maliyet senaryolarının hesaplanması "Antalya Kent Merkezi Sosyo-EkonomikDemografik Yapı, İstihdam ve Yaşam Memnuniyeti Araştırması" anket verilerine dayanmaktadır (Koç ve Mert, 2009). Anketlerden elde edilen betimsel istatistiklere göre, Antalya nüfusunun \%80'inin sağlık güvencesi (SSK, BAĞ-KUR ve Emekli Sandığı) varken, \%14'ü herhangi bir sağlık güvencesine sahip değildir. Diğer \%5,8'i ise yeșil karttan yararlanmaktadır. İşsizlik oranı \%7.3 düzeyindedir. Antalya kent merkezinde ortalama gelir birey için 1.056 TL ve hane halkı için ise 1.635 TL'dir (Tablo 3). Merkez ilçelere göre gelir ortalaması en yüksek olan ilçe Konyaaltı iken en düşük ilçe Kepez'dir (Tablo 4). En yüksek ortalama gelir ile en düşük ortalama gelir arasındaki fark, yaklaşık \%62 oranındadır. Yani, Tablo 4'teki verilere göre Kepez, Konyaaltı ilçesine göre \% 62 civarında daha düşük gelire sahiptir. İlçeler arasında ortalama gelir farklılıkları, ilçeler arasındaki gelir dağılımımın ne kadar eşitsiz olduğunu göstermektedir.

Antalya'da gelir dağılımındaki eşitsizlik ve adaletsizliği gösteren bir diğer önemli gösterge ise anket sonuçlarından hesaplad1ğımız Lorenz eğrisi ve Gini katsayısıdır ${ }^{12}$.

\section{Tablo 3}

Antalya Kent Merkezinde Ortalama Aylık Gelir İstatistikleri

\begin{tabular}{|l|r|r|}
\hline & \multicolumn{1}{|c|}{$\begin{array}{c}\text { Hane Aylık } \\
\text { Geliri }\end{array}$} & \multicolumn{1}{c|}{$\begin{array}{c}\text { Birey Aylık } \\
\text { Geliri }\end{array}$} \\
\hline Ortalama & $1.635,66$ & $1.056,04$ \\
\hline Medyan & $1.360,00$ & 800.00 \\
\hline Tepe Değeri & $1.000,00$ & 1.000 .00 \\
\hline St. Sapma & $1.215,31$ & 841.75 \\
\hline Çarpıklık & 2,67 & 4,20 \\
\hline Minimum & 250.00 & 50.00 \\
\hline Maximum & $1.0000,00$ & 1.0000 .00 \\
\hline
\end{tabular}

Lorenz eğrisi, Antalya'da gelir dağılımındaki eşitsizliği açıkça ortaya koymaktadır (Tablo 5). Bu eğriye göre hane halkının en düşük gelirine sahip yüzde 5'lik dilimi gelirin yüzde 0.77 'sini almaktadır. Hane halk1nın en düşük gelire sahip \%36'lık dilimi gelirin \%15.2'sini alırken, hane halkının en yüksek gelire sahip yaklaşık \% $4^{\prime}$ lük dilimi ise gelirin yaklaşık \%15'ni almaktadır. Yani, hane halklarının en yüksek gelire sahip $\% 4^{\prime}$ lük dilimi Antalya gelirinin \%15'ni elde ederken, geri kalan $\% 96^{\prime}$ lik dilimdeki hane halkları ise gelirin \%85'ini elde etmektedir. Diğer yandan hane halklarının en yüksek

\section{Tablo 4}

Antalya Kent Merkezinde Ortalama Aylık Gelir İstatistikleri

\begin{tabular}{|l|r|r|r|r|r|r|}
\hline İlçe & \multicolumn{1}{c|}{ Ortalama } & \multicolumn{1}{c|}{ Medyan } & \multicolumn{1}{c|}{ Minimum } & \multicolumn{1}{c|}{ Maximum } & \multicolumn{1}{c|}{ St. Sapma } & \multicolumn{1}{c|}{ Çarpıklık } \\
\hline Konyaaltı & $2.074,23$ & $1.725,00$ & 500.00 & $5.500,00$ & $1.280,94$ & 0,81 \\
\hline Muratpaşa & $1.985,60$ & $1.800,00$ & 250.00 & $10.000,00$ & $1.287,39$ & 2,04 \\
\hline Döşemealt1 & $1.657,89$ & $1.200,00$ & 500.00 & $9.000,00$ & $1.886,15$ & 3,59 \\
\hline Aksu & $1.411,56$ & $1.205,00$ & 500.00 & $4.000,00$ & 765.14 & 1,49 \\
\hline Kepez & $1.269,04$ & $1.000,00$ & 400.00 & $9.800,00$ & 985.01 & 4,23 \\
\hline
\end{tabular}

\footnotetext{
${ }^{12}$ Lorenz eğrisi ve Gini katsayılarının hesaplanması tekniği için bkz. Özdemir ( 2001:113-119
} 


\section{Tablo 5}

Lorenz Eğrisi

\begin{tabular}{|c|c|c|c|c|c|c|c|}
\hline & $\begin{array}{c}\text { Gelir Aralığ1 } \\
\text { Orta Değeri } \\
(\mathrm{A})\end{array}$ & $\begin{array}{c}\text { Eşdeğer } \\
\text { Hane Bü- } \\
\text { yüklüğ̈̈ (B) }\end{array}$ & $\begin{array}{c}\text { Gelir } \\
(\mathrm{AXB})\end{array}$ & $\begin{array}{c}\text { Hane } \\
\text { Büyüklüğ̈ } \\
(\%)\end{array}$ & Gelir (\%) & $\begin{array}{c}\text { Hane } \\
\text { Birikimli } \\
\text { Yüzde }\end{array}$ & $\begin{array}{c}\text { Gelir } \\
\text { Birikimli } \\
\text { Yüzde }\end{array}$ \\
\hline $0-500$ & 250,0 & 67,25 & $16.812,500$ & 5,04 & 0,77 & 5,04 & 0,77 \\
\hline $501-1000$ & 750,5 & 417,25 & $313.146,125$ & 31,26 & 14,42 & 36,30 & 15,20 \\
\hline $1001-2000$ & $1.500,5$ & 531,25 & $797.140,625$ & 39,80 & 36,71 & 76,10 & 51,91 \\
\hline $2001-3000$ & $2.500,5$ & 208,25 & $520.729,125$ & 15,60 & 23,98 & 91,70 & 75,89 \\
\hline $3001-4000$ & $3.500,5$ & 57,5 & $201.278,750$ & 4,31 & 9,27 & 96,01 & 85,16 \\
\hline $4001-5000$ & $4.500,5$ & 25,75 & $115.887,875$ & 1,93 & 5,34 & 97,94 & 90,50 \\
\hline $5000-10000$ & $7.500,0$ & 27,5 & $206.250,000$ & 2,06 & 9,50 & 100,00 & 100,00 \\
\hline Toplam & & $\mathbf{1 . 3 3 4 , 7 5}$ & $\mathbf{2 . 1 7 1 . 2 4 5 , 0 0}$ & $\mathbf{1 0 0 , 0 0}$ & $\mathbf{1 0 0 , 0 0}$ & & \\
\hline
\end{tabular}

\section{Lorenz Eğrisi}

Hanehalkı Gelirine Göre, Antalya (2009)

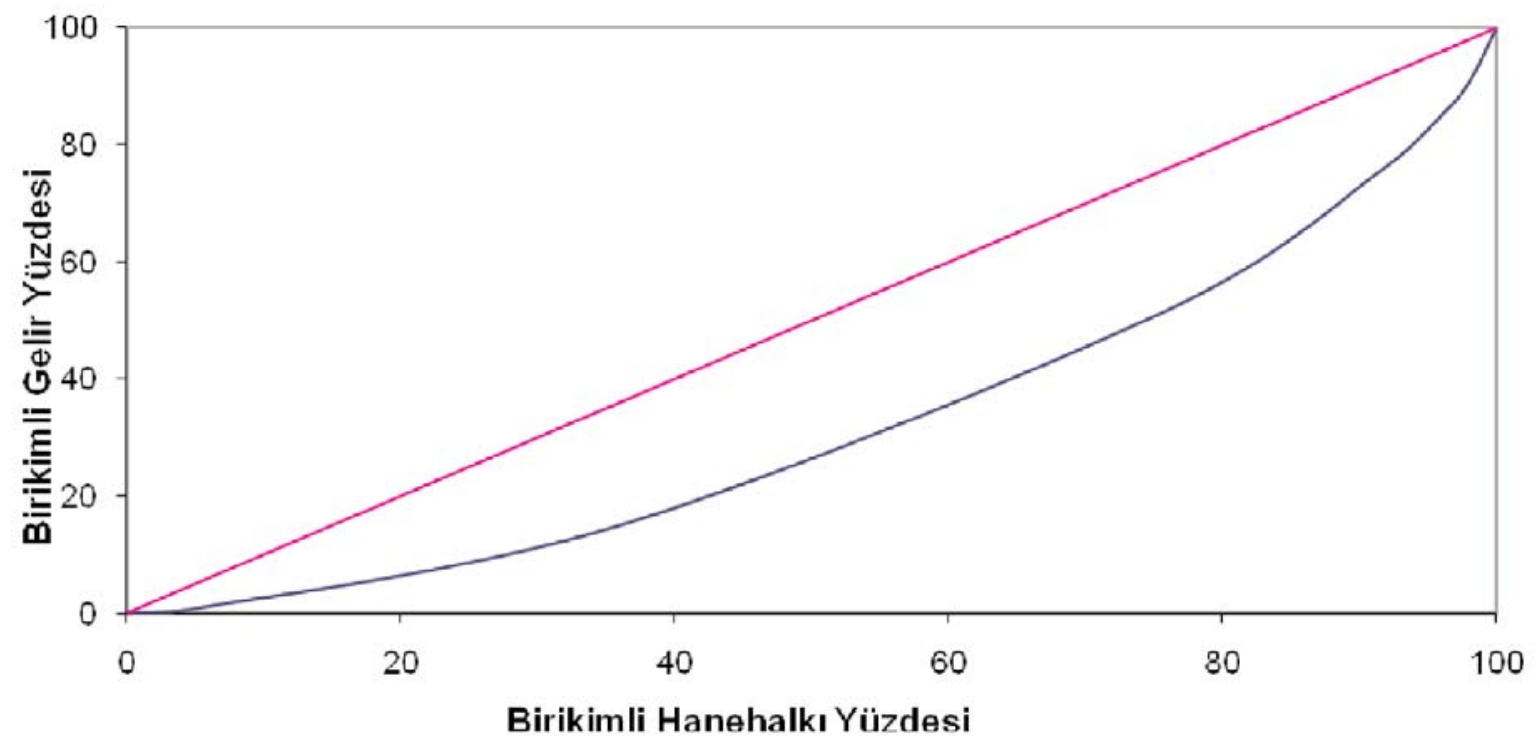

gelire sahip \%2'lik dilimi, toplam gelirlerin yaklaşık \%10'unu almaktadır. Antalya için Gini katsayısı ise 0.34 olarak hesaplanmıştır (bkz. EK 1). Gini katsayısının 1'de mutlak gelir eşitsizliğini ve 0 'da eşitliği gösterdiği dikkate alınırsa Antalya için 0.34 değerindeki Gini katsayısı, gelirin hane halkları arasında eşit dağılmadığını göstermektedir. Diğer yandan, TÜİK'nun 2008 yılı Gelir ve Yaşam Koşulları Araştırması Sonuçlarına göre Türkiye için hesapladığ 1 Gini katsayısı- nın 0.41 olduğu düşünüldüğünde, Antalya'da gelir dağılımı eşitsizliğinin, Türkiye ortalamasının altında olduğunu söylemek mümkündür.

\subsection{Yoksulluk Ölçütleri ve Antalya'da Yok- sulluk}

Anket verilerinden hareketle TÜİK 2008 yoksulluk ölçütleri kullanılarak açlık sınırı, yoksulluk sınırı ve göreli yoksulluk sınırı aşağıdaki gibi hesaplanmıştır . 
A. Açlık (Gıda Yoksulluğu) Sınırı Altında Yașayan Fert ve Haneler (Eșdeğer Yetișin Ölçeği).

Açlık sınırı altında aylık geliri olan kişilerin yaşadığ 1 hane oran $1 \% 0.83$, tahmini hane say1s1 1.434 (172.399 x 0.0083) ve hanelerde ortalama birey sayısı ise 4,75'tir. Açlık sınırının altında yaşayan tahmini kişi sayısı $6.811(1.434 \times 4,75)^{\prime}$ dir. Açlık sınırının altında yaşayan hanelerin yarısı (717 hane ve 3.226 kişi) Muratpaşa ilçesi ve diğer yarısı ise Kepez ilçesinde (717 hane ve 3.585 kişi) yaşamaktadır.

B. Yoksulluk Sınırı (Gıda ve Gıda-Dışı Mal ve Hizmetleri Kapsamaktadır)

Yoksulluk sinırı altında aylık geliri olan hane oranı \%13.3, tahmini hane sayıs 22.939 (172.399x 0,133). Yoksulluk açığ 1 (yoksulluk sinırı-hane aylık geliri) ise ortalama olarak 156 TL'dir. Yoksulluk sinırı altındaki hanelerin büyük bir kısmı Kepez (\%62.5) ve Muratpaşa ilçelerinde yaşamaktadır (Tablo 5). Yoksulluk açığı açısından değerlendirildiğinde ise yoksulluk açığının en fazla (201 TL) olduğu ilçe Muratpaşa ve en düşük ol- duğu (122 TL) ilçe ise Döşemealtı'dır.

C. Yoksulluk Sınırı (Eşdeğer Yetişkin Ölçeği Kullanılarak Fert ve Hane İçin)

Yoksulluk sinırının altında geliri olan kişilerin yaşadı $\breve{g}_{1}$ hane oranı $\% 24.9$, tahmini hane say1s1 43.010 (172.399 x 0.249), hanelerdeki ortalama birey sayıs1, 3,28 ve tahmini kişi sayısı ise $141.073(43.010 \times 3,28)$. Yoksulluk açı̆̆1 ise ortalama olarak 88,3 TL'dir. Yoksulluk açığının en fazla olduğu ilçeler s1rasıyla Aksu ve Muratpaşa iken, en düşük olduğu ilçeler ise sırasıyla Kepez, Döşemaltı ve Konyaaltı'dır.

\section{Yoksulluk Sınırı (Fert Başına Günlük $\underline{4,3 \text { \$ Altında Yaşayan Yoksullar) }}$}

Antalya'da Fert için günlük 4,3 dolara tekabül eden aylık 193,5 TL altında geliri olan kişilerin yaşadı ğ 1 hane oranı 0.07 , tahmini hane say1sı 12.186 (172.399 x 0.070), hanelerdeki ortalama birey sayıs 3,46 ve tahmini kişi sayısı ise $44.357(12.186 \times 3,46)$ 'dir. Yoksulluk açığ 1 ise ortalama olarak yaklaşık 36 TL'dir. Yoksulluk açığının en fazla olduğu ilçeler sırasıyla Kepez ve Muratpaşa'dır.

\section{Tablo 6}

Yoksul Hanelerin İlçelere Göre Dağılımı

\begin{tabular}{|l|c|c|c|}
\hline İlçe & $\begin{array}{c}\text { Yüzde } \\
\mathbf{( \% )}\end{array}$ & $\begin{array}{c}\text { Yoksulluk Oranı } \\
(\mathbf{\%})\end{array}$ & $\begin{array}{c}\text { Yoksul Hane Sayısı } \\
\text { Tahmini }\end{array}$ \\
\hline Kepez & 62.5 & 8.3 & 14.337 \\
\hline Muratpaşa & 23.4 & 3.1 & 5.376 \\
\hline Aksu & 7.8 & 1.0 & 1.792 \\
\hline Döşemealtı & 4.7 & 0.6 & 358 \\
\hline Konyaaltı & 1.6 & 0.2 & $\mathbf{2 2 . 9 3 9}$ \\
\hline Toplam & $\mathbf{1 0 0 . 0}$ & $\mathbf{1 3 . 3}$ & \\
\hline
\end{tabular}

13 Açlık sınırı, yoksulluk sınırı ve göreli yoksulluk sınırı rakamları, her halkı büyüklüğü (1'den 10 kişiye kadar) dikkate alınarak hesaplanmıştır. Hane halkı büyüklüklerine göre açlık sınırı, yoksulluk sınırı ve göreli yoksulluk sınırı rakamları için bakınız: TÜİK 2008 Yoksulluk Çalışması Sonuçları.

14 Her hane halkı büyüklüğüne göre hane toplam geliri, hanede bulunan eşdeğer yetişkin fert sayısına bölünerek bulunmaktadır. Eşdeğerlik ölçeği hesaplamaları için bkz. TUİK, Tüketim Harcamaları, Yoksulluk ve Gelir Dağılımı: Sorularla Resmi İstatistik Dizisi-6, Eylül 2008. 


\section{Tablo 7}

Yoksuluk Sınırı Altında Yaşayan Kişilerin Bulunduğu Hanelerin İlçelere Göre Dağılımı

\begin{tabular}{|l|c|c|c|c|}
\hline İlçe & $\begin{array}{c}\text { Yüzde } \\
(\mathbf{\%})\end{array}$ & Yoksulluk Oranı & $\begin{array}{c}\text { Tahmini Hane } \\
\text { Sayısı }\end{array}$ & $\begin{array}{c}\text { Yoksulluk sınırı } \\
\text { altında yaşayan } \\
\text { tahmini kişi sayısı }\end{array}$ \\
\hline Kepez & 63.3 & 0.158 & 27.240 & $89.618,5$ \\
\hline Muratpaşa & 23.3 & 0.058 & 10.036 & $33.920,6$ \\
\hline Aksu & 5.8 & 0.014 & 2.509 & $8.505,2$ \\
\hline Döşemealtı & 5.8 & 0.014 & 2.509 & $7.501,7$ \\
\hline Konyaaltı & 1.7 & 0.004 & 717 & $1.526,9$ \\
\hline Toplam & $\mathbf{1 0 0 . 0}$ & $\mathbf{0 . 2 4 9}$ & $\mathbf{4 3 . 0 1 0}$ & $\mathbf{1 4 1 . 0 7 3}$ \\
\hline
\end{tabular}

E. Göreli Yoksulluk (Medyan Gelirin Yarısının Altında Geliri Olan Haneler)

Göreli yoksulluk oranı (medyan gelirin yarıs1=1.360/2), \%19 ve göreli yoksulluk s1nır1 altında olan tahmini hane sayısı ise 32.980 (172.399 x 0.191). Göreli yoksulluk açı̆̆ı ise ortalama olarak 117 TL'dir. Göreli yoksulluk açığının en yüksek olduğu ilçe Muratpaşa, düşük olan ilçeler ise sırasıyla Konyaaltı, Kepez, Döşemealtı ve Aksu'dur (Tablo 8).

\section{F. Yoksulluk Profili}

Yoksul hanelerin profili (yoksulluk sinırı ölçütü kullanılarak) incelendiğinde hane halkı reislerinin yaklaşık \%34'ü 31-40 yaş ve \%44'ü ise 40-60 yaş aralığındadır. Göreli olarak orta yaş grubunda yoksulluk oranının yüksekliği, yoksulluğun kalıcı olma riskini arttırmaktadır. Anket sonuçlarına göre yoksul hane halkı reislerinin \%60'ının ilkokul ve \%75'nin ilköğretim (ilkokul + ortaokul) mezunu olmaları yoksul hane halkı reisinin eğitim durumu ile yoksulluk arasinda bir ilişkinin olduğunu göstermektedir. Bu bulgu, yoksulluğun azalmasında eğitim düzeyinin önemli olduğunu göstermektedir. Yoksulların iş durumu analiz edildiğinde yoksul hane halkı reislerinin yaklaşık \%34'ü

\section{Tablo 8}

Yoksul Hanelerin İlçelere Göre Dağılımı

\begin{tabular}{|l|c|c|c|}
\hline İlçe & Yüzde (\%) & Yoksulluk Oranı (\%) & Tahmini Hane Sayısı \\
\hline Kepez & 62.0 & 0.118 & 20.433 \\
\hline Muratpaşa & 23.9 & 0.045 & 7.887 \\
\hline Döşemealtı & 5.4 & 0.010 & 1.792 \\
\hline Aksu & 4.3 & 0.008 & 1.434 \\
\hline Konyaaltı & 4.3 & 0.008 & 1.434 \\
\hline Toplam & 100.0 & 0.191 & 32.980 \\
\hline
\end{tabular}


ücretli, \%20.3'ü emekli ve \%19'u ev hanım1dır. Bu bulgu özellikle çalışan yoksullar için oldukça dikkat çekicidir. Yani, yoksulların yaklaşık üçte biri çalışmalarına karşın yoksulluk sınır altında yaşamaktadır. Ayrıca, yoksul hane reislerinin önemli bir kısmı da emekli ve ev hanımlarından oluşmaktadır.

Antalya anket sonuçları yoksulluk ile hane halkı büyüklüğü arasındaki ilişkinin pozitif olduğunu yani hane büyüklüğü arttıkça yoksulluğun da arttığını göstermektedir. Antalya için bu bulgu TÜİK 2008 Yoksulluk Çalışması Sonuçları'nı destekler niteliktedir. Ayrıca, bağımlı değişkenin yoksulluk açığı (Y), bağımsız değişkenlerin ise hane halk1 büyüklüğü (X1) ve gelir (X2)'in olduğu bir model için kullanılan En Küçük Kareler (EKK) yöntemi ile Tablo 9'daki istatistiksel sonuçlar elde edilmiştir. Görsel olarak bakıldığında, eşdeğer hane büyüklüğ ü ile yoksulluk açığı arasında aynı yönde güçlü bir korelasyon olduğu görülmektedir (bkz. EK 2).

Tablo 9'daki regresyona göre, teorik olarak beklenildiği gibi hane halkı büyüklüğü ile yoksulluk açı̆̆ı arasında aynı yönde, anlamlı ve hane geliri ile yoksulluk açı̆̆ı ara- sında ise ters yönde, anlamlı bir ilişki bulunmuştur. Regresyon sonuçlarına göre hane halkı büyüklügüündeki 1 kişilik bir artış, yoksulluk açı̆̆ını yaklaşık 162 TL arttırmaktadır. Hane halkı gelirlerindeki 1 TL'lik artış ise yoksulluk açığını yaklaşık 0.87 TL azaltmaktadır. Sonuçta hane halkı büyüklüğü yoksulluğu olumsuz etkilerken, gelirlerdeki artış yoksulluğu azaltmaktadır.

Yukarıdaki anket sonuçları Antalya'da yoksulluk ve işsizlikle mücadelede önemli bulgular sağlamaktadır. Öncelikle nüfusun yaklaşık olarak \%14'ünün sağlık şemsiyesi altında olmaması, \%6'sının yeşil karttan yararlanması, işsizlik oranının \%7.3 düzeyinde olması, gelir dağılımındaki adaletsizlikler ve yoksulluk, sosyal hastalıkların ulaştığ yutları göstermesi açısından önemlidir. Antalya kent merkezinde 6.811 kişinin açlik sınırı, 22.939 hanenin yoksulluk sınırı, eşdeğer yetişkin fert hesaplamada 43.010 hane ve 141.073 kişinin yoksulluk sınırı, 32.980 hanenin göreli yoksulluk sınır altında kaldığ1 ve günlük 4.3 dolar altında geliri olan hane sayısının 12.186 olduğu dikkate alındığında Antalya'da yoksulluk ve işsizlikle mücadelenin çok önemli olduğu görülmektedir.

\section{Tablo 9}

Yoksulluk Açığının Modellenmesi (Ekk Regresyonu)

Bağımlı Değişken: Yoksulluk Açığı, $\quad$ Metot : EKK

\begin{tabular}{|l|c|c|c|}
\hline Bağımsız Değişkenler & Katsayı & t-istatistiği & p değeri \\
\hline Sabit & 194.9299 & 7.682 & 0.000 \\
\hline Hane Büyüklüğü & 162.4528 & 29.293 & 0.000 \\
\hline Hane geliri & -0.869094 & -20.439 & 0.000 \\
\hline R & 0.92 & Akaike kriteri & 10.129 \\
\hline Düzeltilmiş R ${ }^{2}$ & F-istatistiği & 489.58 \\
\hline Durbin Watson ist. & 0.92 & & \\
\hline
\end{tabular}

$\hat{Y}=195+162.4 X 1-0.87 X 2$ 
Anket sonuçlarının ortaya çıkardığ 1 tablo, Antalya'ya yapılan sosyal harcamaların yetersizliğini açıkça ortaya koymaktadır.

\section{3. İstihdam Garantisi ya da Gelir Garantisi Politikasi İzlenmesi Durumunda Maliyet Senaryolar}

Anket sonuçlarına dayanarak Antalya'da sosyal hak temelli bir gelir garantisi ya da istihdam garantisinin uygulanmasi durumunda hesapladığımız olası maliyet senaryoları, Tablo 10, Tablo 11 ve Tablo 12 'da özetlenmiştir. Değişik yoksulluk ölçütleri kullanılarak (fert ve haneler için) yoksulluk açı̆̆ına dayanan maliyet senaryoları, nakit gelir ya da kamuda istihdam karşılığ ödeme yapılması durumunda toplam mali- yetlerin Antalya GSMH'sinin yüzde 0.18 ile 0.62 arasında değișebileceğini göstermektedir (Tablo 10 ve Tablo 11). Yoksullara yapılacak ödemelerde yoksulluk açığının dikkate alınmasının en büyük avantajı, hükümet ya da yerel yönetimlerin kaynakları israf etmeden etkin ve adil bir şekilde bu kesimlere transferini sağlamasıdır. Bu durumda yoksulluk sinırı altında kalan birey ya da haneler, elde ettikleri ortalama gelir ile yoksulluk sınırı geliri arasındaki fark kadar karşılıksız nakit gelir elde edecekler ya da kamuda istihdam edileceklerdir. Hükümet ya da yerel yönetimlerin hangi politika seçeneğini tercih edeceği büyük ölçüde yoksulluk ve işsizliğe ilişkin sosyolojik, kurumsal ve iktisadi şartlara bağlı olacaktır.

Tablo 10

Açlık, Yoksulluk ve Göreli Yoksulluk Açığını Kapatacak Maliyet Senaryoları (Nakit Gelir Ödemesi ya da İstihdam Karşılığı)

\begin{tabular}{|c|c|c|c|c|}
\hline Fertler* & \multicolumn{2}{|c|}{ Sayılar } & $\begin{array}{c}\text { Toplam Maliyet (TL) } \\
\text { (fert*yoksulluk aclog } 1 * 12 \text { av) }\end{array}$ & Antalya GSMH'ye \\
\hline Açlık Sınırı & Fert & 6.811 & 596.643 & 0.0 \\
\hline Yoksulluk Sınırı & Fert & 141.073 & 149.480 .950 & 0.62 \\
\hline $\begin{array}{l}\text { Günlük 4,3\$ Altında } \\
\text { Geliri Olanlar }\end{array}$ & Fert & 44.357 & 62.277 .228 & 0.25 \\
\hline
\end{tabular}

* Eşdeğer Yetişkin

\section{Tablo 11}

Açlık, Yoksulluk ve Göreli Yoksulluk Açı̆̆ını Kapatacak Maliyet Senaryoları (Nakit Gelir Ödemesi ya da İstihdam Karşılığı)

\begin{tabular}{|c|c|c|c|c|c|}
\hline Haneler & $\begin{array}{l}\text { Yoksulluk } \\
\text { Oranı } \\
\text { \% }\end{array}$ & \multicolumn{2}{|c|}{ Sayılar } & $\begin{array}{c}\text { Toplam Maliyet (TL) } \\
\left.\text { (hane* yoksulluk açığ } 1^{*} 12 a y\right)\end{array}$ & $\begin{array}{l}\text { Antalya GSMH'ye } \\
\text { Oranı (2008), \% }\end{array}$ \\
\hline Açlık Sınırı & 0.83 & Hane $^{*}$ & 1434 & 125.618 & - \\
\hline \multirow{2}{*}{ Yoksulluk Sınırı } & & Hane & 43.010 & 45.573 .396 & 0.62 \\
\hline & 13.3 & Hane $^{* *}$ & 22.939 & 42.941 .808 & 0.17 \\
\hline $\begin{array}{l}\text { Göreli Yoksulluk S1- } \\
\text { nırı }\end{array}$ & 19.0 & Hane** & 32.980 & 45.908 .160 & 0.19 \\
\hline $\begin{array}{l}\text { Günlük 4,3\$ Altında } \\
\text { Geliri Olanlar }\end{array}$ & 0.07 & Hane ${ }^{*}$ & 12.186 & 17.109.144 & 0.07 \\
\hline
\end{tabular}

* Eşdeğer yetişkinlerin yaşadı̆̆ 1 haneler

** Fertlerin yaşadı ̆̆ $ı$ haneler 
Yoksulluk ve işsizlikle mücadelede kullanılabilecek yoksulluk açığı yöntemi yanında Arjantin, Hindistan gibi ülkelerde uygulanan bir diğer yöntem, doğrudan hane reisine ödeme yapılmasıdır (hane reisinin çocukları okula gönderme, mesleki eğitim gibi bazı koşulları yerine getirmek şartıyla yapilan ödemelerdir). Uluslararası deneyimler bölümünde ifade edildiği gibi Arjantin (hane reisine asgari ücretin yarısı) ve Hindistan'da (hane reisine asgari ücretin üçte biri) uygulanan istihdam garanti politikalarının izlenmesi durumunda ortaya çkabilecek maliyetler tahmin edilmeye çalışılacaktır. Bu noktada hane reisine ödeme yapilırken dikkat edilmesi gereken husus, bu hane halklarının ne kadar yoksul olduklarıdır. Antalya yoksulluk ve işsizlikle ilgili anket verilerine göre daha önce de ifade edildiği gibi yoksul hane reislerinin \%54.3'ü ücretli çalışan ve emeklilerden; \%45.7'si ise ev hanımı, yevmiyeli, kendi hesabına çalışanlar ve işsizlerden oluşmaktadır. Dolayısiyla yoksul haneler arasında çalışan ve emekli olanların belli bir ücret ve emekli maaşı aldıkları dikkate alındığında bu hanelerin reislerine sahip oldukları yoksulluk açıkları kadar ödeme yapılması gerekecektir. Diğer yandan hiç çalışmayan, işsiz ya da geçici işlerde çalışan hane reisleri de bulunmaktadır. Dolayısıyla çalışan ve emeklilere yoksulluk açı̆̆ 1 kadar; geri kalanlara ise önerilen net asgari ücret kadar ödeme yapılması, diğer ülke örneklerine göre daha makul görünmektedir. Bu varsayımları dikkate alarak yoksullukla mücadelenin maliyetini hesaplamak için birinci maliyet senaryosu Arjantin'deki gibi hane reisine asgari ücretin yarısı (haftada 20 saat karşıl1ğinda) kadar ödeme yapmayı kapsamaktadır. İkinci senaryo ise Hindistan'daki gibi hane reisine asgari ücretin üçte biri oranında (yılda 100 iş günü karşılığı) ödeme yapmaya dayanmaktadır.

$\mathrm{Bu}$ çalışmadaki farklı yoksulluk ölçütleri kullanılarak hane reislerine Arjantin'deki gibi net asgari ücretin yarısı kadar yani 270 TL ödenmesi durumunda ortaya çıacak maliyetin Antalya GSMH'sine oranı yüzde 0.09 ile yüzde 0.40 arasındadır (Tablo 12).
Yoksulluk için yapılacak bu ödemenin Antalya'nın merkezi yönetim bütçe giderlerine oranı ise yüzde 0.08 ile yüzde 3.9 aralığında değişmektedir. Benzer şekilde ikinci senaryo olarak adlandırdığımız Hindistan'daki gibi net asgari ücretin üçte biri kadar yani 170 TL yoksul hane reislerine ödenmesi durumda ise toplam maliyetlerin Antalya GSMH'sine oranı yüzde 0.06 ile 0.29 arasında değişebileceğini göstermektedir. Toplam maliyetlerin Antalya merkezi yönetim bütçe giderlerine oranı ise yüzde 0.5 ile yüzde 2.5 arasında değişmektedir (Tablo 12).

Antalya kent merkezi için yapılan yukarıdaki maliyet senaryoları, gerek ilin milli gelir düzeyi gerekse ilin merkezi yönetim bütçe gider büyüklügüule karşılaştırıldığında nakit gelir ödemesi/istihdam garantisi sağlanması politikalarının uygulanabilir olduğunu göstermektedir. Daha önceki bölümde ifade ettiğimiz gibi devletin, merkez belediyelerin ve sivil toplum kurumlarinin tüm Antalya'yı kapsayan toplam sosyal yardımların Antalya GSMH'sine oraninin yüzde 0.12 olduğu düşünüldüğünde, yapılan sosyal yardımların oldukça yetersiz olduğu görülmektedir. Diğer yandan önerilen politikaların maliyet senaryoları dikkate alındığında nakit gelir ödemesi/istihdam sağlanması politikalarının yol açacağı harcamaların bir kismının SYDTF ve belediyelerden karşılanan harcamaların yerini alacağından mali kaynak yetersizliği itirazları geçersiz kalacaktır. Dolayısıyla yoksulluk ve işsizliğe yönelik sosyal hak temelli politikaların maliyetleri makul görünmektedir. Ayrıca, bu politikaların arz kapasitesini arttırması yanında talep-yanlı olarak çarpan yoluyla ekonomik büyümeye katk1 yapacağı, devletin vergi gelirlerini arttıracağ 1 ve böylece söz konusu politika maliyetlerini düşüreceğini ileri sürmek mümkündür. 


\section{Tablo 12}

Farklı Yoksulluk Ölçütleri Dikkate Alınarak Hane Halkı Reisine Yapılacak Ödemelerle İlgili Maliyet Senaryoları

\begin{tabular}{|c|c|c|c|c|c|c|c|}
\hline Haneler & $\begin{array}{c}\text { Hane Halkı } \\
\text { Sayıs }\end{array}$ & $\begin{array}{c}\text { Toplam } \\
\text { Maliyet } \\
\text { (Net Asgari } \\
\text { Ücretin } \\
\text { \%50'i) }\end{array}$ & $\begin{array}{c}\text { Antalya } \\
\text { GSMH'ye } \\
\text { Oranic \% }\end{array}$ & $\begin{array}{c}\text { Antalya } \\
\text { Bütçe } \\
\text { Giderlerine } \\
\text { Oranı }^{\mathrm{c}} \\
\%\end{array}$ & $\begin{array}{l}\text { Toplam Ma- } \\
\text { liyet (Net } \\
\text { Asgari Üc- } \\
\text { retin } \\
\left.\% 33^{\prime} u\right)^{b}\end{array}$ & $\begin{array}{c}\text { Antalya } \\
\text { GSMH'ye } \\
\text { Oranic }^{c} \\
\%\end{array}$ & $\begin{array}{c}\text { Antalya } \\
\text { Bütçe } \\
\text { Giderlerine } \\
\text { oranı }^{c} \\
\%\end{array}$ \\
\hline Açlık Sınırı & Hane 1.434 & 390.048 & - & - & 243.780 & - & - \\
\hline $\begin{array}{l}\text { Yoksulluk } \\
\text { Sinırı (1) }\end{array}$ & Hane $43.010 \mathrm{a}$ & 88.431 .336 & 0.40 & 3.49 & 64.844 .112 & 0.29 & 2.5 \\
\hline $\begin{array}{l}\text { Yoksulluk } \\
\text { Sinırı (2) }\end{array}$ & Hane $22.939 a$ & 57.279.312 & 0.25 & 2.26 & 44.690 .112 & 0.18 & 1.7 \\
\hline $\begin{array}{l}\text { Günlük } 4,3 \$ \\
\text { Altında } \\
\text { Geliri Olanlar }\end{array}$ & Hane $12.186 a$ & 20.902 .140 & 0.09 & 0.08 & 14.219.304 & 0.06 & \\
\hline
\end{tabular}

(1) Eşdeğer yetişkinlerin yaşadığı haneler; (2) Fertlerin yaşadı ̆̆g haneler;

(a) Yoksul hane halkı reislerinin \%54.3'ü ücretli çalışan ve emeklilerden oluşurken; geri kalan \% 45.7'ü ise ev hanımı, yevmiyeli, kendi hesabına çalışan, işsiz ve öğrencilerden oluşmaktadır. Dolayısıyla çalışan ve emeklilere yoksulluk açığı kadar ödendiği ve geri kalanlara ise önerilen asgari ücret oranı kadar ödendiği varsayılmaktadır.

(b) 2010 yılı itibariyle net asgari ücret 576.57 TL'dir.

(c) 2008 yılı için Antalya'nın GSMH'sinin 22,4 milyar TL ve merkezi yönetim bütçe giderleri ise toplam milyar 527 milyon TL'dir.

Yoksullara ve işsizlere yönelik yoksulluk açı̆̆ı ya da asgari ücretin yarısı ya da üçte biri kadar ödemeyi gerektiren politika önlemleri nakit gelir ödeme şeklinde olabileceği gibi tıpkı Arjantin, Hindistan ve Güney Afrika örneklerinde olduğu gibi kamu işlerinde istihdam karşılı̆̆ında da çalışılabilir. Burada önemli bir nokta özellikle gelir garantisi durumunda karşılıksız olarak ödemelerin yaratacağ 1 yoksulluk kültürü gibi sorunlarla ilgilidir. Bu sorunu aşmak için bir yandan devlet yoksullara ve işsizlere temel bir yaşam standardı sağlama sorumluluğunu yerine getirirken, diğer yandan yoksul ve işsizlerin de bu olanakları iyi değerlendirmeleri ve kişisel sorumluluklarını yerine getirecek şeklide hareket etmelidir (Gül, 2007:200-201). Bu bağlamda karşılıksız gelir garantisi sağlamak yerine insana yatırım yapan, onları eğiten ve emek piyasasına hazırlayan istihdamı garanti eden politikalara ihtiyaç vardır. Yoksulluk ve işsizlikle mücadelede uluslararası deneyimlerin gösterdiği gibi belli bir maaş karşılığı hem meslek edindirme kurslarına gidecek hem de kamu kesiminde çalışabilecek bir model makul görünmektedir. Bu politika önlemleri bir yandan işsiz ve yoksul insanları çalışma yaşamina kazandıracak, diğer yandan ise daha adil ve eşitlikçi bir toplumun yaratılması yönünde ciddi bir adım atılmış olacaktır. İnsanların iş sahibi olmalarının yarattığ1 ekonomik ve sosyal etkiler, belli bir gelir elde etmenin çok ötesine gitmektedir. Çal1şan ve yaşanabilir gelir elde eden insanlar, vatandaş olarak daha özgürce karar vermektedir. Özgür bireylerin (vatandaşların) oluşturduğu toplumlar ise daha fazla sivilleşmekte ve demokratikleşmektedir. Oysa bugün uygulanan neo-liberal sistem sistemin yol açtığ isssizlik, yoksulluk ve gelir dağlımındaki eşitsizlikler, toplumsal dayanışmayı ve demokrasiyi tehdit etmektedir. 


\section{SONUÇ}

İşsizliğin ve yoksulluğun bugün ulaştığ 1 boyut dikkate alındığında, ekonomik büyümenin eşitsiz gelişimi hem mali hem de sosyal olarak kabul edilemez. Piyasa ekonomisinin işsizliği ve yoksulluğu çözmede yetersiz kaldığ 1 dikkate alındığında, toplumum bu temel problemlere hayırseverlik anlayışından uzak, sosyal hak temelli bir yaklaşım geliştirilmelidir. Bu bağlamda bugün Arjantin, Hindistan, Güney Afrika gibi "istihdam güvencesi" ve Fransa gibi temel gelir (vatandaşlık geliri) gibi sosyal hak temelli sosyal politika önlemleri dikkatlice analiz edilmelidir. Bu politikalar hakkında, geçen kısa süre dikkate alındığında, henüz kesin yargida bulunmak güç olmakla birlikte uygulamalar başarıyla devam etmektedir. Kamunun istihdam garantisi politikasını uygulayan bu ülke deneyimleri ve bu politikaların uygulanması durumunda olası maliyetleri hesaplayan bilimsel çalışmalar, bu politikaların uygulanabilir olduğunu göstermektedir. Yerel ölçekte Antalya örneği de bu yaklaşımı destekler mahiyettedir.

Sonuç olarak, piyasa ekonomilerinin tam istihdamı sağlamada yetersiz olması durumunda işsiz ve yoksulları toplum için sosyal ve ekonomik olarak yararlı faaliyetlerde kullanacak şekilde hükümetlerin yurtiçi politikalarını yeniden tasarlaması gerekmektedir. Bu tür politikalar istihdam edilmeyen işgücünün verimli istihdam alanlarında kullanılmasını sağlayacak ve özel sektörün ihtiyaç duyması durumunda her zaman çalışmaya hazır işgücü arz edilecektir. Diğer yandan sosyal hak temelinde dikkatli şekilde uygulanabilecek politikalar sosyal barışın, sivilleşmenin ve demokratikleşmenin zeminini de hazırlayacaktır. Bugün neo-liberal sistemin yol açtığı eşitsizliklerin, toplumsal dayanışmayı tehdit ettiği düşünüldüğünde, toplumsal barışın ve dayanışmanın olmadığ 1 bir toplumda, sosyal dışlanma ve güvensizlik insanları yalnızlaştırmakta ve çaresizleştirmektedir. Dolay1sıyla adalet, eşitlik ve toplumsal dayanışmanın meşruiyet kazanmadığı, in- sanların özgürleşmediği bir toplumsal yapıda ne demokrasi gelişebilir ne de toplumsal barış sağlanabilir.

Türkiye bağlaminda son dönemlerde istihdam yaratmayan büyüme, gelir adaletsizlikleri, bölgesel gelişmişlik farkları, göçler, krizler gibi yapısal sorunların yeni yoksullar yaratmaya devam ettiği dikkate alındığında, yoksulları ve işsizleri gözeten politikaların geliştirilmesi, sosyal devlet anlayışının bir gereğidir. Antalya kent merkezi ölçeğinde yapılan bu çalışma, Türkiye genelinde yoksulluk ve işsizlilikle mücadelede uygulanabilecek alternatif politikalarin geliştirilmesinde ve bu politikaların maliyetlerinin hesaplanmasında yeni araştırmalara ihtiyaç olduğunu göstermektedir. 


\section{References}

Antalya Büyük Şehir Belediyesi, 2008 yıllık Raporu.

Antonopoulos R., (2007), The Right to a Job, the Right Types of Projects: Employment Guarantee Policies from a Gender Perspective, The Levy Economics Institute of Bard Colege, Working Paper No.516.

Antonopoulos R., (2009), Promoting Gender Equality, Job Creation in Home Based Care and Early

Artus, Patrick, (2009), Special Report, NATIXIS, 09 June 2009-No:173.

Antalya Ticaret ve Sanayi Odası, (2007), Rakamlarla Antalya Ekonomisi.

Buğra ve Sinmazdenir, (2007), Yoksullukla Mücadelede İnsani ve Etkin Bir Yöntem: Nakit Gelir Desteği, Bir Temel Hak Olarak Vatandaşlik Gelirine Doğru içinde Buğra, Ayșe ve Keyder, Çağlar (derl.), Boğaziçi Üniversitesi Sosyal Formu, İletişim Yayınları, İstanbul.

Childhood Development: The Case of South Africa: Employment Guarantee Policies Responding to the Current Economic Crisis and Contributing to Long Term Development Conference June 22-23, 2009, The Levy Economics Institute.

Center for Full Employment and Price Stability (CFEPS), http:/www.cfeps.org (Erişim Tarihi: 5 Ocak 2010).

Chakraborty P., (2009), Policy Space, Fiscal Space, and Financing for NREGA, Employment Guarantee Policies Responding to the Current Economic Crisis and Contributing to Long Term Development Conference June 22-23, 2009, The Levy Economics Institute.
Chevalier, E. Isabelle (2008), Promoting Contractual Obligation with Job Seekers: How to Boost Return to Employment, MISEP MEETING, Achieving Activation of Jobseekers: Successful Strategies of Case Managment, Centre Pierre Mendes-France.

The Centre of Full Employment and Equity (CofFEE), http://e1.newcastle.edu.au / coffee (Erişim Tarihi: 23 Ocak 2010).

Gordon, Wendell (1997), Job Assurance: The Job Guarantee Revisited, Journal of Economic Issues 32 (3), s. 826-834.

Gül, Hüseyin (2007), ABD Örneği'nde Üçüncü Yol: Yoksulluğa ve Eşitsizliğe Yaklaşımı ve Yeni Sağ ile Bir Karşılaştırma, ODTÜ Gelişim Dergesi, 34 (Aralik), 195-215.

http:/ /www.epwp.gov.za/index.asp?c=We lcome, Public Works, Republic of South Africa, (Erişim Tarihi 25 Ekim 2010).

http:/ / www.info.gov.za/speeches/2009/ 09040614451002.htm, South Africa Goverment Online (Erişim Tarihi 25 Ekim 2010).

Işık, Sayım ve Mert, Mehmet (2009), İstihdam ve İşsizliği Sorununu Çözmeye Yönelik İstihdam/Gelir Garantisi Politikasının Uygulanabilirliği: Antalya Örneği, Uluslararası Sosyal Haklar Sempozyumu'nda Sunulan Bildiri, 2223 Ekim 2009 Akdeniz Üniversitesi.

Işık, Sayım (2009a), İstihdam Bağlamında Neo Liberal Yaklaşıma Post Keynesyen Karşı Duruş: Devletin Nihai İşveren Olma Rolü, İş, Güç Endüstri İlişkileri ve İnsan Kaynakları Dergisi (Nisan sayısı).

Işık, Sayım (2009b), Tam İstihdam ve Fiyat İstikrar1 Kapsamında Neo-Liberal Yaklaşımlara Post-Keynesyen Karşı Duruşlar: Devletin Nihai İşveren Olma Rolü, Ekonomik Yaklaşım Dergisi (Gazi Üniversitesi İktisat Bölümü), Kış sayısı. 
Jaffer PC, (2007), India's National Rural Employment Guarantee Scheme (NREGA)-Localised Implementation in Gulbarga District of Karnataka, http: / / www.solutionexchangeun.net.in/NREGA/documents/NREG A-Gulbarg.pdf (Erişim Tarihi: 12 Aralık 2009).

Kaboub, Fadhel (2007a), Employment Guarantee Programs: A Survey of Theories and Policy Experiences, The Levy Economics Institute of Bard College, Working Paper no:498, s.1-23.

Kaboub, Fadhel (2007b), ELR-led Economic Development: A Plan for Tunisia, The Levy Economics Institute of Bard College, Working Paper no:499, s. 1-30.

Kepez Belediyesi, 2008 y1llık Raporu.

Koç, A.Ali ve Mert, Mehmet (2009), Antalya Kent Merkezi Sosyo-EkonomikDemografik Yapı, İstihdam ve Yaşam Memnuniyeti Araştırması, Akdeniz Üniversitesi, Bilimsel Araştırma Projeleri Koordinasyon Birimi, Proje No: 2009.01.0106.002.

Konyaaltı Belediyesi, 2008 yıllık Raporu.

Kostzer D., (2009), Some Lessons from the Argentinean Plan Jefes de Hogar Employment as a Strategy for Human Development, Employment Guarantee Policies Responding to the Current Economic Crisis and Contributing to Long Term Development Conference June 22-23, 2009, The Levy Economics Institute.

Kregel, Jan (1999), Price Stability and Full Employment as Complements in a New Europe: A Market-Based Price Stabilization Policy for the New ECB, Full Empoyment and Price Stability in a Global Economy içinde P. Davidson and J.Kregel (derl.), Edward Elgar.
Kregel, Jan (2006), ELR as an Alternative Development Strategy, Employment Guarantee Policies: Theory and Practice", A Conference of The Levy Institute of Bard College.

Lieuw-Kie-Song M.R., (2009), The South African Expanded Public Works Programme (EPWP), Employment Guarantee Policies Responding to the Current Economic Crisis and Contributing to Long Term Development Conference June 22-23, 2009, The Levy Economics Institute.

Minsky, Hyman (1965), The Role of Employment Policy", Poverty in America içinde Gordon (derl.), CA: Chandler.

Minsky, Hyman (1986), Stabilizing an Unstable Economy, London: Yale University Press.

Mitchell, William F. ve Martin J. Watts. 1997. The Path to Full Employment, Australian Economic Review 30(4), s. 433-435.

Mitchell, W. Ve J.Muysken (2008), Full Empoyment Abandoned, Edward Elgar, Cheltenham, UK.

Mosler, Warren (1997-98), Full Employment and Price Stability, Journal of Post Keynesian Economics, vol. 20. no. 2. 167182.

Mosler, Warren ve Forstater M. (1999), A General Framework for the Analysis of Currencies and Commodities, Full Employment and Price Stability in a Global Economy içinde P. Davidson and J.Kregel (derl.), Edward Elgar.

Muratpaşa Belediyesi, 2008 yıllık Raporu.

Mütevellioğlu, N. ve Işık, S. ( 2009, Türkiye'de Neo Liberal Politikaların Emek Piyasası Üzerindeki Etkileri, Küreselleşme, Kriz ve Türkiye'de Neoliberal Dönüşüm içinde Mütevellioğlu N ve Sönmez, Sinan (derl.), Bilgi Üniversitesi Yayınları, Şubat 2009. 
Özdemir, Durmuş (2001), Applied Statistics for Economics and Business, İstanbul Bilgi University Press, İstanbul, 2001, s.113-119.

Papadimitriou D.B., (2008), Promoting Equality Through an Employment of Last Resort Policy, The Levy Economics Institute of Bard Colege, Working Paper No. 545.

Papadimitriou D.B., (2009a), During and After the Crisis: Why Is an Employer of Last Resort Policy Needed?, Employment Guarantee Policies Responding to the Current Economic Crisis and Contributing to Long Term Development Conference June 22-23, 2009, The Levy Economics Institute.

Papadimitriou, Dimitri (2009c), 12th Regional Seminar for Labour-intensive Construction, 8 - 12 October 2007, International Convention Centre (ICC) KwaZulu Natal, South Africa, Prioritising Employment Creation in Government Policies, Programmes and Investments, Conference Proceedings: Panel on Employment Guarantee Policies, http://www.economistsforfullemployment.org/news/Durban_panel .doc (Erişim Tarihi: 11 Aralık 2009).

Şengül ve Fisunoğlu (2009), Adana Kentsel Kesimde Yoksulluk, EconAnadolu 2009: Anadolu Uluslararası İktisat Kongresi'nde sunulmuş bildiri, 17-19 Haziran 2009, Eskişehir, Türkiye.

T.C. Sosyal Yardımlaşma ve Dayanışma Fonu, 2008 yıllık Raporu.

Tcherneva, Pavlina (2005), The Economic Viability of Universal Guarantees in Sovereign Currency Nations, Center for Full Employment and Price Stability Working Paper No:49.
Tcherneva P.R., (2003), Job or Income Guarantee?, CFEPS, Working Paper No.29.

Tcherneva P., ve Wray L.R., (2005a), Can Basic Income and Job Guarantees Deliver on Their Promises, CFEPS, Working Paper No.42.

Tcherneva, P. ve Wray (2005b), Is Jefes de Hogar an Employer of Last Resort Program?: An Assesment of Argentina's ability to Deliver the Promise of Full Employment and Price Stability, CFEPS Working Paper No:43.

Tcherneva, P. ve Wray (2005c), Employer of Last Resort: A Case Study of Argentina's Jefes Program, CFEPS Working Paper No:41.

Tcherneva, P. ve Wray (2005d), Gender and the Job Guarantee: The Impact of Argentina's Jefes Program on Female Heads of Householder, CFEPS Working Paper No:41

Tepepa M., (2009), Community Development and ELR: A Gender Perspective on the Jefes y Jefas de Hogar, Employment Guarantee Policies Responding to the Current Economic Crisis and Contributing to Long Term Development Conference June 22-23, 2009, The Levy Economics Institute.

TÜİK, (2008), İşgücü İstatistikleri

TUİK, (2008), Tüketim Harcamaları, Yoksulluk ve Gelir Dağılımı: Sorularla Resmi İstatistik Dizisi-6, Eylül 2008.

TUİK, (2009), 2008 Yoksulluk Çalışması Sonuçları, Haber Bülteni, sayı: 2005.

Wray, Randall L. (2007), The Employer of Last Resort Programme: Could It Work for Developing Countries?, Economic and Labour Market Papers, International Labour Office, Geneva. 
EK 1: GINI KATSAYISININ HESAPLANMASI

\begin{tabular}{|c|c|c|c|c|c|c|}
\hline $\mathrm{X}_{\mathrm{i}}$ & \multirow{2}{*}{$\begin{array}{c}\text { Hanehalkı } \\
\text { Birikimli } \\
\text { Yüzde }\end{array}$} & $Y_{i}$ & \multirow{2}{*}{$\begin{array}{c}\text { Gelir } \\
\text { Birikimli } \\
\text { Yüzde }\end{array}$} & (1) & $(2)$ & \multirow[b]{2}{*}{$(1) x(2) / 2$} \\
\hline $\mathrm{i}=0, \ldots, 7$ & & $i=0, \ldots, 7$ & & $\mathrm{X}_{\mathrm{i}}-\mathrm{X}_{\mathrm{i}-1}$ & $Y_{i}+Y_{i-1}$ & \\
\hline $\mathrm{X}_{0}$ & 0,00 & $\mathrm{Y}_{0}$ & 0,00 & & & \\
\hline $\mathrm{X}_{1}$ & 5,04 & $\mathrm{Y}_{1}$ & 0,77 & 5,04 & 0,77 & 1,950679 \\
\hline $\mathrm{X}_{2}$ & 36,30 & $\mathrm{Y}_{2}$ & 15,20 & 31,26 & 15,97 & 249,6321 \\
\hline $\mathrm{X}_{3}$ & 76,10 & $\mathrm{Y}_{3}$ & 51,91 & 39,80 & 67,11 & 1335,479 \\
\hline $\mathrm{X}_{4}$ & 91,70 & $\mathrm{Y}_{4}$ & 75,89 & 15,60 & 127,80 & 997,0063 \\
\hline $\mathrm{X}_{5}$ & 96,01 & $\mathrm{Y}_{5}$ & 85,16 & 4,31 & 161,06 & 346,9099 \\
\hline$X_{6}$ & 97,94 & $\mathrm{Y}_{6}$ & 90,50 & 1,93 & 175,66 & 169,4458 \\
\hline $\mathrm{X}_{7}$ & 100,00 & $\mathrm{Y}_{7}$ & 100,00 & 2,06 & 190,50 & 196,2455 \\
\hline & & & & & Toplam & 3296,669 \\
\hline & & & & & Gini & 0,34067 \\
\hline
\end{tabular}

Gini $=\frac{\alpha}{\alpha+\beta} \quad \beta=\frac{\sum_{i=1}^{k}\left[\left(X_{i}-X_{i-1}\right)\left(Y_{i}+Y_{i-1}\right)\right]}{2}$

$\alpha=0$ olduğunda Gini katsayısı $=0$ ise mutlak eşitlik durumu vardır. $\beta=0$ olduğunda Gini katsayısı $=1$ ise mutlak eşitsizlik vardır. Formülde k Gelir-frekans tablosundaki (Tablo 1) gelir grubu sayısını ifade etmektedir. Bizim çalışmamızda $k=7$ olarak alınmıştır. $X_{0}=Y_{0}=0$ ve $X_{k}=Y_{k}=100$ değerleri, Lorenz eğrisinin uç noktalarıdır. Eğer yüzdeleri kullanırsak $\alpha+\beta=5000$ olacaktır. Çünkü, iki eksenin çarpımının (100*100) ikiye bölünmesi bu sayıyı verir. Bu durumda $\alpha=5000-\beta$ olacaktır. Gini katsayısının da $\alpha /(\alpha+\beta)$ değerine ya da $\alpha / 5000$ değerine eșit olduğu görülmektedir. Tablo 2 'de de görüleceği üzere $\beta=3296,669$ ve $\alpha=5000-3296,669=1703,331$; sonuç olarak Gini katsayısı 0,34067 olarak hesaplanmıştır (Özdemir, 2001:113-119).

\section{EK 2: YOKSULLUK AÇIĞI VE HANE BÜYÜKLÜĞÜ}

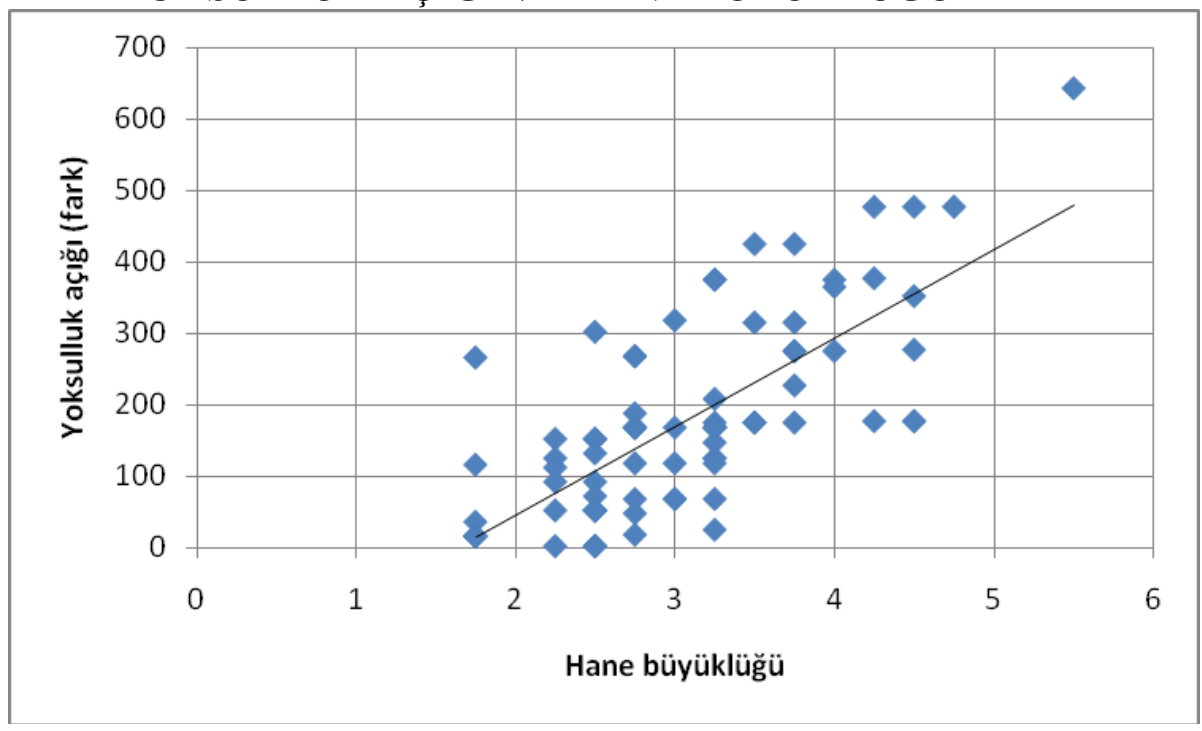


